\title{
Antidiabetic Effect and Mode of Action of Cytopiloyne
}

\author{
Cicero Lee-Tian Chang, ${ }^{1}$ Hsien-Yueh Liu, ${ }^{1}$ Tien-Fen Kuo, ${ }^{2}$ Yi-Jou Hsu, ${ }^{2}$ Ming-Yi Shen, \\ Chien-Yuan Pan, ${ }^{4}$ and Wen-Chin Yang ${ }^{2,4,5}$ \\ ${ }^{1}$ Department of Veterinary Medicine, National Chung Hsing University, 402 Taichung, Taiwan \\ ${ }^{2}$ Agricultural Biotechnology Research Center, Academia Sinica, 128 Academia Road, Section 2, Nankang, 115 Taipei, Taiwan \\ ${ }^{3}$ Research Center, China Medical University and Hospital, Graduate Institute of Clinical Medical Sciences, China Medical University, \\ 40402 Taichung, Taiwan \\ ${ }^{4}$ Institute of Zoology, National Taiwan University, 10617 Taipei, Taiwan \\ ${ }^{5}$ Department of Life Sciences, National Chung Hsing University, 402 Taichung, Taiwan
}

Correspondence should be addressed to Wen-Chin Yang; wcyang@gate.sinica.edu.tw

Received 3 November 2012; Accepted 29 January 2013

Academic Editor: Srinivas Nammi

Copyright (C) 2013 Cicero Lee-Tian Chang et al. This is an open access article distributed under the Creative Commons Attribution License, which permits unrestricted use, distribution, and reproduction in any medium, provided the original work is properly cited.

Cytopiloyne was identified as a novel polyacetylenic compound. However, its antidiabetic properties are poorly understood. The aim of the present study was to investigate the anti-diabetic effect and mode of action of cytopiloyne on type 2 diabetes (T2D). We first evaluated the therapeutic effect of cytopiloyne on T2D in $\mathrm{db} / \mathrm{db}$ mice. We found that one dose of cytopiloyne reduced postprandial glucose levels while increasing blood insulin levels. Accordingly, long-term treatment with cytopiloyne reduced postprandial blood glucose levels, increased blood insulin, improved glucose tolerance, suppressed the level of glycosylated hemoglobin $A_{1 c}$ $\left(\mathrm{HbA}_{1 \mathrm{c}}\right)$, and protected pancreatic islets in $\mathrm{db} / \mathrm{db}$ mice. Next, we studied the anti-diabetic mechanism of action of cytopiloyne. We showed that cytopiloyne failed to decrease blood glucose in streptozocin- (STZ-)treated mice whose $\beta$ cells were already destroyed. Additionally, cytopiloyne dose dependently increased insulin secretion and expression in $\beta$ cells. The increase of insulin secretion/expression of cytopiloyne was regulated by protein kinase $\mathrm{C} \alpha(\mathrm{PKC} \alpha)$ and its activators, calcium, and diacylglycerol (DAG). Overall, our data suggest that cytopiloyne treats T2D via regulation of insulin production involving the calcium/DAG/PKC $\alpha$ cascade in $\beta$ cells. These data thus identify the molecular mechanism of action of cytopiloyne and prove its therapeutic potential in T2D.

\section{Introduction}

Insulin is indispensable for glucose homeostasis in mammals. Insulin biosynthesis at transcriptional and translational levels, and its secretion in $\beta$ cells, is well regulated by blood glucose [1]. Calcium ions, potassium ions, phospholipase C, DAG, phosphatidylinositol triphosphate (IP3), PKC, and protein kinase A (PKA) are involved in insulin secretion and, likely, insulin biosynthesis in pancreatic $\beta$ cells [2]. On binding to insulin, an insulin receptor initiates a signaling cascade and eventually causes glucose uptake in peripheral tissues. Any defect in insulin synthesis/secretion or action, or both, may result in hyperglycemia, a major pathological feature of type 2 diabetes (T2D) [3]. Such hyperglycemia is detrimental to $\beta$ cells and insulin target tissues, and this glucotoxicity is clinically relevant as a cause of diabetesrelated complications such as nephropathy, retinal blindness, neuropathy, peripheral gangrene, and cardiovascular disease [4]. Therefore, maintenance of glycemic homeostasis is the most common therapeutic aim for patients with T2D.

Diabetes is a life-threatening metabolic disease, afflicting around $5 \%$ of the world population. Over $90 \%$ of the diabetic population is diagnosed with T2D mellitus $[5,6]$. Current antihyperglycemic drugs are insulin secretagogues, insulin sensitizers, inhibitors of sugar cleavage, and glucagon-like peptide-1 (GLP-1), all of which control homeostasis of blood sugar by different mechanisms [7]. Common drawbacks of such drugs include significant side effects, decreased efficacy over time, low cost-effectiveness, and only partial anti-diabetic effect of each individual drug [8]. Of note, 
secretagogues with the ability to prevent adverse effects (e.g., weight gain and hypoglycemia), to stimulate insulin biosynthesis, or to protect $\beta$ cells from death are rare [7, 9]. GLP-1, an injectable peptide drug, may be the only one reported to fit these criteria [10]. In view of patients' welfare, there is still an obvious need for development of antidiabetics that protect against hypoglycemia, enhance insulin synthesis, or improve $\beta$-cell protection.

Plants are an extraordinary resource for anti-diabetic remedies $[11,12]$. One outstanding example is metformin, a derivative of guanidine that was first isolated from French lilac and is a commonly prescribed insulin sensitizer for treatment of T2D [13]. Further, extracts prepared from the plant Bidens pilosa, a member of the Asteraceae family, were shown to have anti-diabetic properties in alloxan-treated mice [14] and have been used to treat patients with diabetes in America, Africa, and Asia $[11,15]$. Two polyacetylenes isolated from $B$. pilosa have demonstrated anti-diabetic properties by two different laboratories [16, 17]. More recently, another polyacetylene, cytopiloyne, was identified in B. pilosa and shown to be highly potent in the prevention of type 1 diabetes via T-cell regulation [18]. B. pilosa and its three polyacetylenes showed glucose-lowering activities in diabetic mice $[16,19$, 20]. However, the long-term therapy and mechanism of these three polyacetylenes for T2D are not known.

The $\mathrm{db} / \mathrm{db}$ mice whose leptin receptor gene is mutated spontaneously develop diabetes because of insulin resistance [21]. STZ-treated mice represent a chemical-inducible model that exhibits insufficient insulin production [22]. Both models reflect main causes of T2D [23]. In this study, we studied the anti-diabetic potential and mechanism of cytopiloyne in $\mathrm{db} / \mathrm{db}$ mice and STZ-treated C57BL mice and in pancreatic $\beta$ cells.

\section{Materials and Methods}

2.1. Ethics Statement. All animals were maintained and handled according to the institutional guidelines and the protocol was approved by the Academia Sinica Animal Care and Utilization Committee (protocol number: OMiIBAYW2010043).

2.2. Chemicals, Cells, and Animals. Dimethyl sulfoxide (DMSO), STZ, nimodipine, EGTA, metformin, glimepiride, brefeldin A, hematoxylin, eosin, phorbol 12-myristate 13acetate (PMA), glimepiride, 1-stearoyl-2-arachidonoyl-snglycerol, cholesterol, and diaminobenzidine tetrahydrochloride were purchased from Sigma-Aldrich (MO, USA). Antiactin, anti-HA, and anti-insulin antibodies were purchased from Santa Cruz Biotechnology (CA, USA). Insulin (Novo Nordisk, NJ, USA) and anti-PKC $\alpha$ (Abcam, MA, USA) and antiphospho-PKC $\alpha$ (Millipore, MA, USA) antibodies were purchased. Cytopiloyne was prepared to $98 \%$ purity from $B$. pilosa as previously described $[17,18]$. Cytopiloyne dissolved in DMSO was stored in a light protected vial at $-20^{\circ} \mathrm{C}$. After one year storage, more than $90 \%$ of the isolated cytopiloyne was stable, as was confirmed by structural determination by NMR spectroscopy. RIN-m5F cells (CRL-11605), a rat $\beta$ cell line, were obtained from the American Type Culture
Collection. Primary pancreatic islets were isolated from fasted Wistar rats obtained from the National Laboratory Animal Center (NLAC) in Taipei, Taiwan. C57BL and db/db mice [24] were obtained from the NLAC. All animals were maintained in the institutional animal facility and handled according to the guidelines of the Academia Sinica Institutional Animal Care and Utilization Committee.

2.3. Drug Administration in $d b / d b$ Mice. For single-dose administration, diabetic $\mathrm{db} / \mathrm{db}$ males aged 6 to 8 weeks, with free access to food, were grouped and tube fed with either $0.2 \mathrm{~mL}$ vehicle ( $1 \mu \mathrm{L}$ DMSO per $1 \mathrm{~mL}$ of PBS), cytopiloyne $(0.1,0.5$, and $2.5 \mathrm{mg} / \mathrm{kg}$ body weight $(\mathrm{BW}))$, or glimepiride $(2.5 \mathrm{mg} / \mathrm{kg} \mathrm{BW})$. After $0.5 \mathrm{~h}$, the levels of postprandial blood sugar and insulin from the mice were monitored for an additional $4 \mathrm{~h}$. For continuous administration, diabetic $\mathrm{db} / \mathrm{db}$ males were grouped and tube-fed with vehicle, cytopiloyne ( 0.5 or $2.5 \mathrm{mg} / \mathrm{kg} /$ day), or glimepiride $(2.5 \mathrm{mg} / \mathrm{kg} /$ day $)$ for the indicated time, while levels of blood sugar, insulin, and glycosylated $\mathrm{HbA}_{1 \mathrm{c}}$ and glucose tolerance in these mice were determined. Unless otherwise indicated, the mice were fasted for $16 \mathrm{~h}$ and then postprandial blood glucose and insulin in these mice were measured. A portion of mice were sacrificed for immunohistochemical staining. The rest were maintained to determine survival rates.

2.4. Drug Administration in STZ-Treated Mice. To deplete pancreatic $\beta$ cells in mice, 6-week-old C57BL females were intraperitoneally injected with STZ at $200 \mathrm{mg} / \mathrm{kg}$. STZ-treated females with postprandial blood sugar over $500 \mathrm{mg} / \mathrm{dL}$ were grouped. Each group was either tube-fed with vehicle $(1 \mu \mathrm{L}$ DMSO per $1 \mathrm{~mL}$ of PBS), cytopiloyne (0.1, 0.5 , and $2.5 \mathrm{mg} / \mathrm{kg})$, or glimepiride $(2.5 \mathrm{mg} / \mathrm{kg})$ or injected with insulin at $2.5 \mathrm{IU} / \mathrm{kg}$ BW. Blood glucose levels were monitored for $4 \mathrm{~h}$. To distinguish sensitizer activity from releaser activity of cytopiloyne, STZ-treated C57BL mice were tube-fed with vehicle, glimepiride $(2.5 \mathrm{mg} / \mathrm{kg})$, metformin (60 mg/kg), and cytopiloyne ( 0.5 and $2.5 \mathrm{mg} / \mathrm{kg}) 1 \mathrm{~h}$ before insulin injection $(2.5 \mathrm{IU} / \mathrm{kg})$. Blood glucose levels in the mice were monitored from 0 to $4 \mathrm{~h}$ after insulin injection.

2.5. Measurement of Glucose, Insulin, and $\mathrm{Hb} \mathrm{A}_{1 \mathrm{c}}$. Glucose levels in mouse blood samples were measured using an Elite glucometer (Bayer, PA, USA). Insulin levels in blood samples or islet cell supernatants were determined by ELISA assays (Mercodia, Uppsala, Sweden). The levels of glycosylated $\mathrm{HbA}_{1 \mathrm{c}}$ in blood samples were measured using a DCA 2000 analyzer (Bayer, PA, USA).

2.6. Insulin Secretion. Pancreatic islets ( 10 islets $/ \mathrm{mL}$ ) from fasted male Wistar rats were incubated with Krebs-Ringer bicarbonate (KRB) buffer [25] containing vehicle $(1 \mu \mathrm{L}$ DMSO per $\mathrm{mL}$ KRB buffer), glimepiride, or cytopiloyne in the absence or presence of glucose for $30 \mathrm{~min}$. The KRB buffer was then collected for ELISA assays.

2.7. Intraperitoneal Glucose Tolerance Test (IPGTT). Male $\mathrm{db} / \mathrm{db}$ mice were administered either vehicle, cytopiloyne at 0.5 and $2.5 \mathrm{mg} / \mathrm{kg} / \mathrm{day}$, or glimepiride at $2.5 \mathrm{mg} / \mathrm{kg} /$ day for 
the indicated time. The mice were fasted for $16 \mathrm{~h}$ before the glucose tolerance test. On days 0 and 42 , each group received an oral dose $(0.2 \mathrm{~mL})$ of vehicle (1 $\mu \mathrm{L}$ DMSO per $1 \mathrm{~mL}$ of PBS), glimepiride, or cytopiloyne (time 0 ) and one intraperitoneal injection with glucose $(0.5 \mathrm{~g} / \mathrm{kg}) 0.5 \mathrm{~h}$ later. The levels of blood sugar were monitored from -0.5 to $3 \mathrm{~h}$ after glucose administration.

2.8. Immunohistochemistry. Pancreata from $\mathrm{db} / \mathrm{db}$ males with continuous drug administration were snap frozen in $O C T$ compound and stained with hematoxylin and eosin or anti-insulin antibody, followed by diaminobenzidine tetrahydrochloride development as previously published [18]. Optimal cutting temperature compound (OCT) is an inert cryosection medium. Multiple parallel sections of each pancreas were analyzed by light microscopy.

2.9. Intracellular Staining for Insulin. Rat pancreatic islets were incubated with vehicle alone $(1 \mu \mathrm{L}$ DMSO per $1 \mathrm{~mL}$ of PBS), cytopiloyne, or glimepiride for $24 \mathrm{~h}$. The islet cells were dissociated into single-cell suspension, stained with antiinsulin antibody and analyzed by fluorescence-activated cell sorting (FACS).

2.10. Real-Time RT-PCR Analysis. Rat pancreatic islets were incubated with vehicle ( $1 \mu \mathrm{L}$ DMSO per $1 \mathrm{~mL}$ of PBS), cytopiloyne, or glimepiride for $24 \mathrm{~h}$. Total RNA isolated from these islets was extracted and converted to cDNA. Realtime RT-PCR was performed with the above cDNA using insulin primers $\left(5^{\prime}\right.$-TGCGGGTCCTCCACTTCAC- $3^{\prime}$ and $5^{\prime}$-GCCCTGCTCGTCCTCTGG- $\left.3^{\prime}\right)$ or L13 primers $\left(5^{\prime}\right.$-AGA TAC CAC ACC AAG GTC CG-3' and $5^{\prime}$-GGA GCA GAA GGC TTC CTG-3').

2.11. Transfection and Luciferase Assays. The phINS-Luc and pRL-TK plasmids contain the human insulin promoter (2347 bp) from the phINS-DCR3 vector [26] linked to the firefly luciferase gene and the thymidine kinase promoter linked to the Renilla luciferase reporter gene, respectively. RIN-m5F cells were transfected with pHACE-PKC $\alpha$ DN plasmid (a gift from Dr J.-W. Soh), pcDNA3 (a control plasmid), phINS-Luc, and/or pRL-TK by lipofectamine or electroporation. After a $24 \mathrm{~h}$ recovery, the cells were treated with vehicle ( $1 \mu \mathrm{L}$ DMSO per $1 \mathrm{~mL}$ of medium), glucose, GF109203X (a PKC inhibitor), glimepiride, or cytopiloyne for an additional $24 \mathrm{~h}$. Subsequently, dual luciferase assays were performed as described [18].

2.12. Detection of Intracellular Calcium. RIN-m5F cells were preloaded with Fura 2-AM $(5 \mu \mathrm{M})$ in modified KrebsHenseleit buffer for $30 \mathrm{~min}$ at $25^{\circ} \mathrm{C}$ for $1 \mathrm{~h}$. After washing, the cells were stimulated with $16.7 \mathrm{mM}$ glucose or cytopiloyne $(7,14$, and $28 \mu \mathrm{M})$. Intracellular calcium was measured using a fluorescence spectrophotometer (CAF 110, Jasco, Tokyo, Japan) at the excitation wavelengths of 340 and $380 \mathrm{~nm}$ and emission wavelength of $500 \mathrm{~nm}$. The ratio of fluorescence intensity at $340 \mathrm{~nm}$ to that at $380 \mathrm{~nm}$ represents the level of intracellular calcium.
2.13. Extraction and Measurement of DAG. RIN-m5F cells were treated with glucose, cytopiloyne, PMA, and glimepiride for $5 \mathrm{~min}$. Total lipids were extracted with ethyl acetate as previously described [27]. The cells were separated on a silica thin layer plate with the first developer of ethyl acetate : acetic acid:trimethylpentane $(9: 2: 5)$ and the second developer of hexane : diethylether: methanol: acetic acid $(90: 20: 3: 2)$. The spot of DAG and cholesterol in each sample was visualized with $15 \%$ sulfuric acid and identified by 1-stearoyl-2arachidonoyl-sn-glycerol and cholesterol.

2.14. Western Blot. RIN-m5F cells were starved in KRB buffer for $30 \mathrm{~min}$. The cells were then treated with vehicle, PMA, $16.7 \mathrm{mM}$ glucose, and cytopiloyne in the absence or presence of EGTA and nimodipine for the indicated time. After extensive washing, the cells were pelleted. The total lysate, cytosolic fraction, and membrane fraction were prepared, followed by SDS-polyacrylamide gel electrophoresis. The membrane was blotted with anti-PKC $\alpha$, anti-phospho-PKC $\alpha$, and anti-actin antibodies. The expression level of HA-tagged PKC $\alpha$-DN in RIN-m5F cells was confirmed using Western blot with antiHA antibody. The effect of GF109203X on PKC $\alpha$ inactivation in $\beta$ cells was confirmed by Western blot (see the species list in the Supplementary Material of Figure 1 available online at http://dx.doi.org/10.1155/2013/685642).

2.15. Statistical Analysis. Data from three independent experiments or more are presented as mean \pm SEM. ANOVA was used for statistical analysis of differences between groups, and $P\left({ }^{*}\right)$ less than 0.05 was considered to be statistically significant.

\section{Results}

3.1. Beneficial Effect of Cytopiloyne on Glucose Lowering, Glucose Tolerance Test, Glycosylation of $\mathrm{HbA}_{1 \mathrm{c}}$, and Islet Preservation. We and others have previously identified three polyacetylenes present in B. pilosa that exhibit antihyperglycemic activities in different diabetic models [16-20]. However, their long-term benefit and mode of action remained unclear. In the study, we investigated the therapeutic effect and mechanism of cytopiloyne, a polyacetylenic glucoside (Figure 1(A)), on T2D. Glimepiride, an anti-diabetic sulfonylurea drug, acts to enhance insulin secretion in pancreatic $\beta$ cells and, in turn, reduces blood glucose. We first evaluated single-dose effects of cytopiloyne on diabetic $\mathrm{db} / \mathrm{db}$ mice. We found that like glimepiride $(2.5 \mathrm{mg} / \mathrm{kg})$, cytopiloyne at doses of 0.1 , 0.5 , and $2.5 \mathrm{mg} / \mathrm{kg}$ significantly reduced postprandial blood glucose levels in a dose-dependent manner in diabetic $\mathrm{db} / \mathrm{db}$ mice (Table 1). We also compared blood insulin levels in the same mice. Both glimepiride and cytopiloyne significantly elevated the blood insulin levels in $\mathrm{db} / \mathrm{db}$ mice compared to vehicle alone (Table 2). These data showed that a single dose of cytopiloyne had anti-hyperglycemic and insulinreleasing effects on $\mathrm{db} / \mathrm{db}$ mice. Next, we investigated longterm therapeutic effects of cytopiloyne in diabetic $\mathrm{db} / \mathrm{db}$ mice. We found that $0.5 \mathrm{mg} / \mathrm{kg}$ cytopiloyne had similar blood sugar-lowering effects on fed $\mathrm{db} / \mathrm{db}$ mice as glimepiride at $2.5 \mathrm{mg} / \mathrm{kg}$ (Figure 1(B)). Additionally, cytopiloyne was 


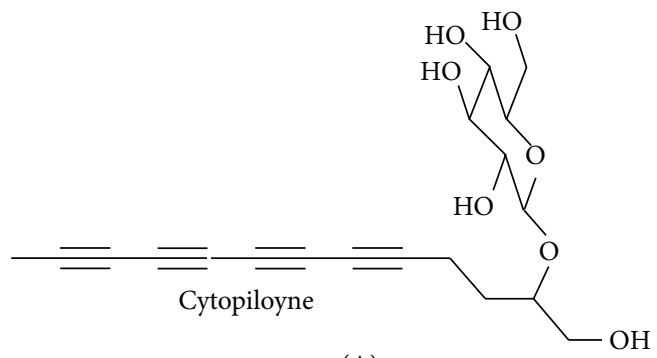

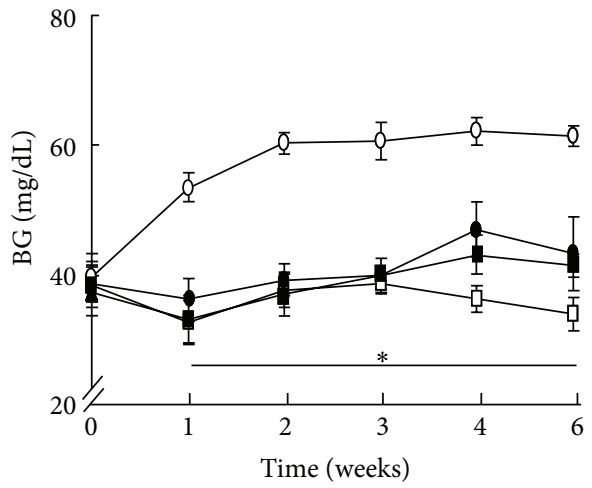

-0- Vehicle $(n=6)$

$\rightarrow-$ CP $2.5 \mathrm{mg} / \mathrm{kg}(n=6)$

(B)

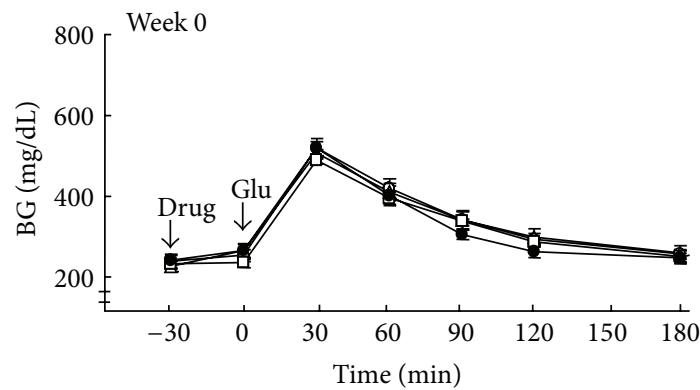

$\multimap-$ Vehicle $(n=6) \quad$ CP $0.5 \mathrm{mg} / \mathrm{kg}(n=6)$

$\rightarrow \operatorname{GLM} 2.5 \mathrm{mg} / \mathrm{kg}(n=6) \rightarrow \mathrm{CP} 2.5 \mathrm{mg} / \mathrm{kg}(n=6)$

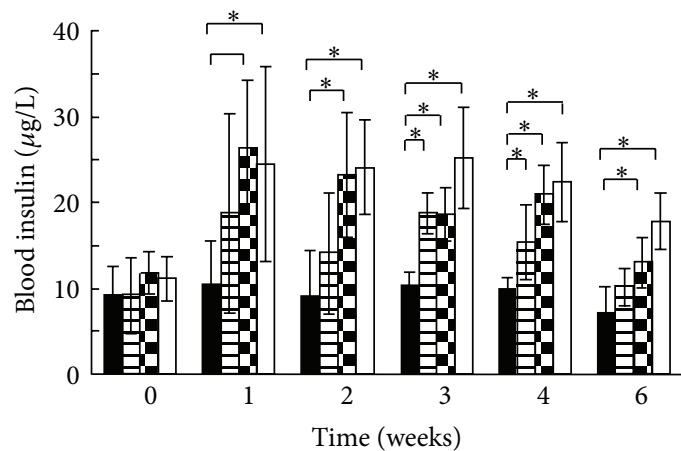

Vehicle $(n=6)$

GLM $2.5 \mathrm{mg} / \mathrm{kg}(n=6)$

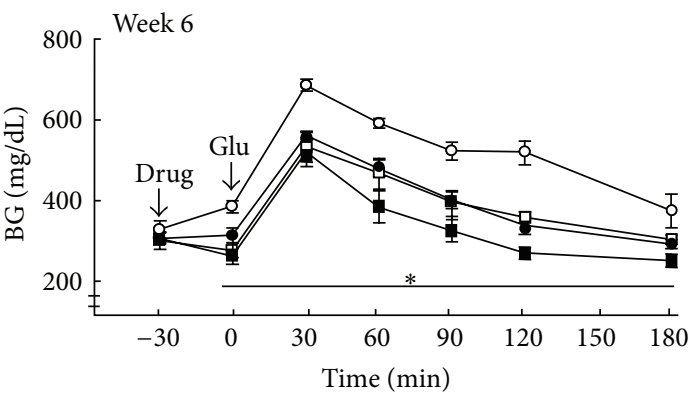

$\multimap-$ Vehicle $(n=6) \quad \square$ CP $0.5 \mathrm{mg} / \mathrm{kg}(n=6)$

$\longrightarrow \operatorname{GLM} 2.5 \mathrm{mg} / \mathrm{kg}(n=6) \longrightarrow \mathrm{CP} 25 \mathrm{mg} / \mathrm{kg}(n=6)$

(D)

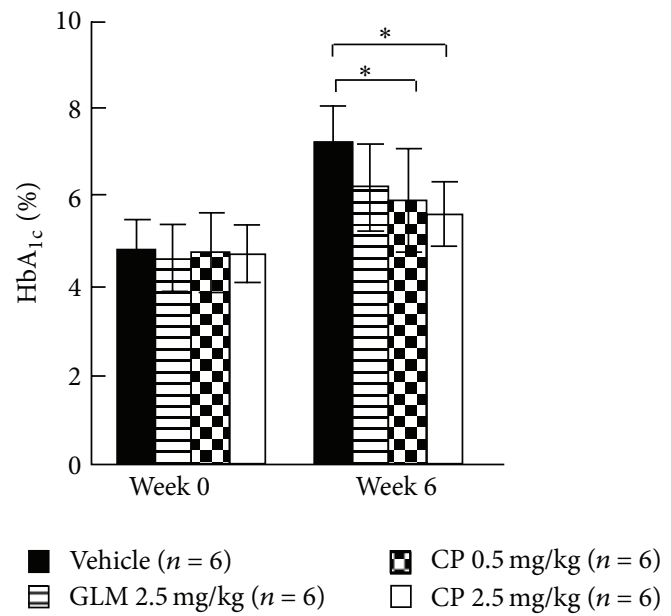

(E)

Figure 1: Continued. 


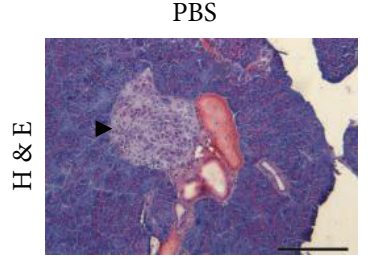

(a)

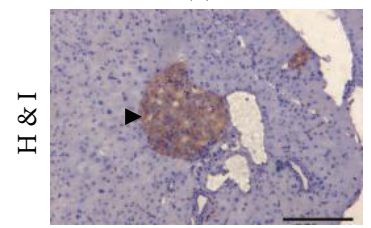

(b)

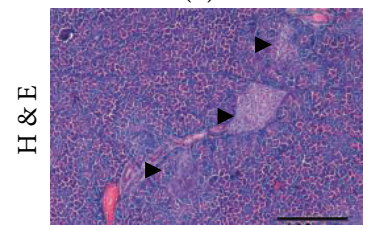

(i)

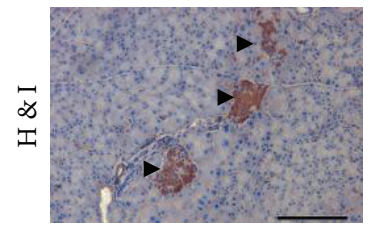

(j)

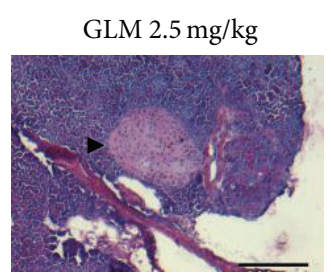

(c)

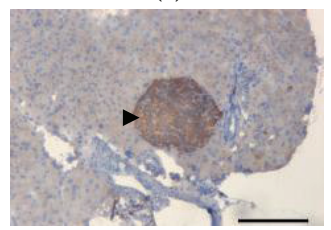

(d)

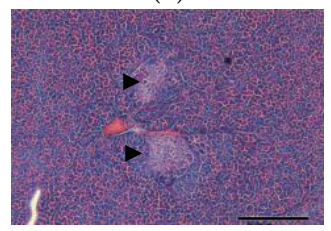

(k)

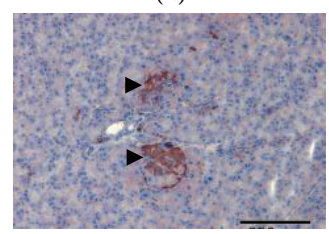

(1)

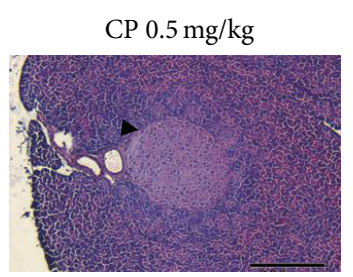

(e)

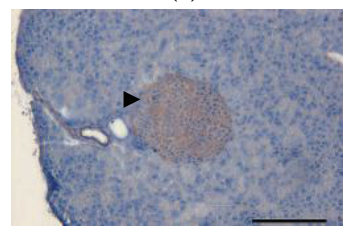

(f)

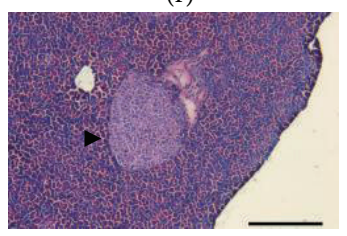

$(\mathrm{m})$

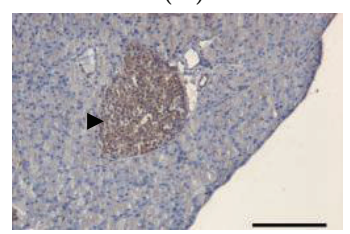

$(\mathrm{n})$

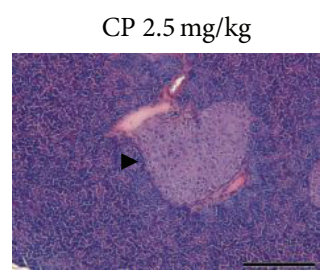

(g)

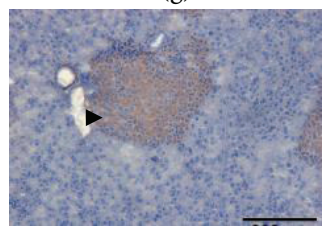

(h)

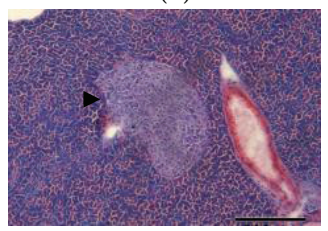

(o)

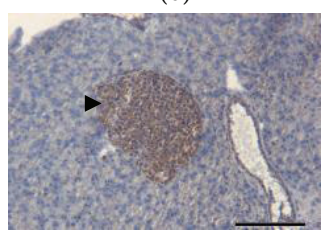

(p)

(F)

FIGURE 1: Anti-diabetic effects of cytopiloyne in db/db mice during long-term treatment. (A) Chemical structure of cytopiloyne. (B) Four groups of 6 to 8 -week-old diabetic db/db mice were tube-fed with vehicle, cytopiloyne (CP, 0.5 and $2.5 \mathrm{mg} / \mathrm{kg} / \mathrm{day}$ ), or glimepiride (GLM, $2.5 \mathrm{mg} / \mathrm{kg} /$ day) from 0 to 6 weeks. Postprandial blood glucose (BG) levels in these mice were measured. (C) Blood insulin levels from the above mice (B). (D) IPGTT was performed in the above $\mathrm{db} / \mathrm{db}$ mice (B) on weeks 0 and 6 after-treatment, and blood glucose levels were monitored for $3.5 \mathrm{~h}$. (E) The percentage of glycosylated $\mathrm{HbA}_{1 \mathrm{c}}$ in whole blood from the above mice (B) was determined 0 and 6 weeks aftertreatment. (F) Pancreata of 8- and 16-week-old db/db males, which had received the same treatment as described in (B) for 2 (images a-h) and 10 (images i-p) weeks, were stained with hematoxylin and eosin (H\&E, images (a), (c), (e), (g), (i), (k), (m), and (o)) or hematoxylin and an antibody against insulin (H\&I, images (b), (d), (f), (h), (j), (l), (n), and (p)). Arrowheads indicate pancreatic islets. Scale bars, $200 \mu \mathrm{m}$. Results are expressed as mean \pm SEM from 3 independent experiments, and $P\left({ }^{*}\right)<0.05$ was considered to be statistically significant. The number of mice $(n)$ is indicated in parentheses.

slightly more efficacious at $2.5 \mathrm{mg} / \mathrm{kg}$ than glimepiride at $2.5 \mathrm{mg} / \mathrm{kg}$. Consistently, cytopiloyne increased blood insulin levels to a greater extent than glimepiride and this increase was dose dependent (Figure $1(\mathrm{C})$ ). We also evaluated the effect of cytopiloyne on glucose tolerance. IPGTT assays showed no difference in glucose tolerance in treated and control mice at week 0 (upper panel, Figure 1(D)). By contrast, cytopiloyne treatment for 6 weeks improved glucose tolerance in $\mathrm{db} / \mathrm{db}$ mice to a greater extent than glimepiride at the same dose $(2.5 \mathrm{mg} / \mathrm{kg}$ ) (lower panel, Figure 1(D)). Glycosylated $\mathrm{HbA}_{1 \mathrm{c}}$ is known to be an excellent indicator of long-term glycemic control. Therefore, we examined the percentage of glycosylated $\mathrm{HbA}_{1 c}$ in $\mathrm{db} / \mathrm{db}$ mice following different treatments. In the blood from 6- to 8-week-old $\mathrm{db} / \mathrm{db}$ mice, $4.8 \% \mathrm{HbA}_{1 \mathrm{c}}$ was glycosylated. However, by 12 to 14 weeks of age, this value had risen to $7.3 \%$ in untreated $\mathrm{db} / \mathrm{db}$ mice. By contrast, $6.3 \%, 6 \%$, and $5.6 \%$ of $\mathrm{HbA}_{1 \mathrm{c}}$ were glycosylated in the blood of age-matched mice following treatment with $2.5 \mathrm{mg} / \mathrm{kg}$ glimepiride or with $0.5 \mathrm{mg} / \mathrm{kg}$ or $2.5 \mathrm{mg} / \mathrm{kg}$ cytopiloyne, respectively (Figure $1(\mathrm{E})$ ). These data suggest that cytopiloyne, which reduced glycosylated $\mathrm{HbA}_{1 \mathrm{c}}$ by $1.3 \%$ and $1.7 \%$ at concentrations of $0.5 \mathrm{mg} / \mathrm{kg}$ or $2.5 \mathrm{mg} / \mathrm{kg}$, respectively, achieves relatively tighter glycemic control than glimepiride, which only decreased glycosylated $\mathrm{HbA}_{1 c}$ by $1 \%$, in $\mathrm{db} / \mathrm{db}$ mice. Diabetic $\mathrm{db} / \mathrm{db}$ mice usually develop severe atrophy of pancreatic islets. We assessed the protective effect of cytopiloyne on islet destruction in $\mathrm{db} / \mathrm{db}$ mice aged 8 and 16 weeks, which corresponded to early and chronic stages of diabetes, respectively [28]. There was no significant difference in pancreatic islets of treated and untreated $\mathrm{db} / \mathrm{db}$ mice at 6 to 8 weeks of age. Twelve- to 14-week-old $\mathrm{db} / \mathrm{db}$ mice, which had received a long-term treatment with vehicle control and glimepiride, had sporadic islets. In sharp contrast, the age-matched $\mathrm{db} / \mathrm{db}$ mice with 
TABLE 1: Blood glucose levels following a single oral dose of cytopiloyne in fed $\mathrm{db} / \mathrm{db}$ mice. Diabetic $\mathrm{db} / \mathrm{db}$ mice aged 6 to 8 weeks, with free access to food, were grouped and tube-fed with vehicle, glimepiride (GLM) at $2.5 \mathrm{mg} / \mathrm{kg} /$ day, and cytopiloyne (CP) at $0.1,0.5$, and $2.5 \mathrm{mg} / \mathrm{kg} /$ day. A half-hour after tube feeding was set as time 0 . Blood samples were collected from the mice at the indicated time intervals $(0,1,2$, and $4 \mathrm{~h})$. The blood glucose levels were determined using a glucometer. The number of mice $(n)$ tested is indicated in parentheses in the first column.

\begin{tabular}{lcccc}
\hline \multirow{2}{*}{ Treatment } & \multicolumn{4}{c}{ Blood glucose level $(\mathrm{mg} / \mathrm{dL})$} \\
& 0 & 1 & 2 & $4(\mathrm{~h})$ \\
\hline Vehicle $(n=8)$ & $365 \pm 9$ & $309 \pm 4$ & $281 \pm 9$ & $240 \pm 11$ \\
GLM 2.5 mg/kg $(n=5)$ & $378 \pm 9$ & $237 \pm 16^{*}$ & $178 \pm 20^{*}$ & $187 \pm 6^{*}$ \\
CP 0.1 mg/kg $(n=7)$ & $373 \pm 6$ & $267 \pm 12$ & $204 \pm 17^{*}$ & $158 \pm 18^{*}$ \\
CP 0.5 mg/kg $(n=7)$ & $369 \pm 27$ & $214 \pm 15^{*}$ & $163 \pm 8^{*}$ & $132 \pm 11^{*}$ \\
CP 2.5 mg/kg $(n=7)$ & $365 \pm 9$ & $207 \pm 11^{*}$ & $147 \pm 12^{*}$ & $129 \pm 11^{*}$ \\
\hline
\end{tabular}

${ }^{*} P<0.05$ as determined by ANOVA.

cytopiloyne treatment showed much greater preservation of islet structure (Figure 1(F)). Accordingly, cytopiloyne treatment resulted in a better survival rate as compared to treatment with glimepiride or vehicle in $\mathrm{db} / \mathrm{db}$ mice (see the species list in the Supplementary Material of Table 1 available online at http://dx.doi.org/10.1155/2013/685642). We also confirmed the preventive effect of cytopiloyne on T2D in $\mathrm{db} / \mathrm{db}$ mice aged 4 weeks that has been previously reported $[29,30]$. Cytopiloyne failed to stop the development of $\mathrm{T} 2 \mathrm{D}$ in $\mathrm{db} / \mathrm{db}$ mice, but it significantly reduced hyperglycemia in these mice compared to the control cohort (see the species list in the Supplementary Material of Figure 2 available online at http://dx.doi.org/10.1155/2013/685642). It should be noted that the blood glucose levels of $\mathrm{db} / \mathrm{db}$ mice in preventive experiments (see the species list in the Supplementary Material of Figure 2(a) available online at http://dx.doi.org/10.1155/2013/685642) and therapeutic experiments (Figure 1(B)) were dissimilar because the ages of the mice examined were different. Collectively, cytopiloyne treatment for diabetes was better than glimepiride in terms of both dosage and therapeutic effects.

\subsection{Cytopiloyne Acts as an Insulin Secretagogue rather than a} Sensitizer. The sugar-reducing and insulin-increasing effects of cytopiloyne raised the possibility that cytopiloyne controls blood sugar in $\mathrm{db} / \mathrm{db}$ mice primarily through stimulating insulin production from $\beta$ cells. Rat primary pancreatic islets are commonly used to test insulin secretion/synthesis because rats have more abundant pancreatic islets than mice and the islets of both species respond to glucose similarly [1]. To examine the role of cytopiloyne in insulin secretion, we treated rat islets with cytopiloyne in KRB buffer containing $16.7 \mathrm{mM}$ glucose. We found that cytopiloyne effectively enhanced insulin secretion in high glucose medium (Figure 2(a)) as well as glucose-free and low-glucose media (see the species list in the Supplementary Material of Figure 3 available online at http://dx.doi.org/10.1155/2013/685642). To confirm that cytopiloyne reduced hyperglycemia by stimulating insulin production from pancreatic $\beta$ cells in vivo, we tested its ability to reduce hyperglycemia and to augment insulin levels in STZ-treated C57BL mice whose $\beta$ cells were already depleted. As expected, cytopiloyne lost its ability to regulate both responses in these mice (Figure 2(b)). In sharp contrast, insulin treatment still diminished blood glucose levels in $\beta$-cell-depleted mice (Figure $2(\mathrm{~b})$ ). To exclude the possibility that cytopiloyne is an insulin sensitizer, we administrated STZ-treated C57BL/6 mice with an oral dose of vehicle, glimepiride, metformin, or cytopiloyne $60 \mathrm{~min}$ before an insulin injection. Both cytopiloyne and glimepiride had little, if any, lowering effect on blood sugar in these mice. However, metformin, an anti-diabetic biguanide drug, acts to sensitize insulin signaling and, in turn, significantly reduced blood glucose levels compared to vehicle alone in these mice (Figure 2(c)). Overall, our results support an insulinreleasing role of cytopiloyne in $\beta$ cells.

\subsection{Cytopiloyne Elevates the Level of Insulin $m R N A$ and} Protein in Pancreatic Islets. Glucose is known to modulate transcription, translation, and secretion of insulin in pancreatic $\beta$ cells [1]. However, current secretagogues act to increase insulin secretion but not synthesis. We have shown that cytopiloyne increases insulin secretion from rat islets (Figure 2(a)). Therefore, we also evaluated the effect of cytopiloyne on insulin expression. We first used an insulin promoter-driven reporter construct to test the effect of different treatments on insulin transcription. Glimepiride had no significant effect on insulin transcription in RIN$\mathrm{m} 5 \mathrm{~F} \beta$ cells, a rat $\beta$-cell line, compared to the low-glucose control (3.3 mM). By contrast, high glucose (16.7 mM) upregulated insulin transcription eleven times; $28 \mu \mathrm{M}$ cytopiloyne augmented insulin transcription five times, and this increase was dose dependent (Figure 3(a)). Next, we examined the expression levels of insulin mRNA relative to those of L13, a house-keeping control gene, in rat islet cells pretreated with low glucose, high glucose, $10 \mu \mathrm{M}$ glimepiride, or cytopiloyne at 7,14 , and $28 \mu \mathrm{M}$ for $24 \mathrm{~h}$. Glimepiride slightly decreased insulin transcription. By contrast, a high concentration of glucose up-regulated insulin transcription five times, while $28 \mu \mathrm{M}$ cytopiloyne resulted in doubled insulin transcription (Figure 3(b)). Further, we examined the effect of cytopiloyne on insulin content inside pancreatic islet cells. FACS is a sensitive method to detect levels of an intracellular protein at the level of an individual cell. Therefore, we used FACS to monitor the content of intracellular insulin. Glucose treatment $(16.7 \mathrm{mM})$ increased the intracellular insulin levels in these cells from $2.3 \%$ to $5.1 \%$ (Figure 3(c)). Consistent with the effect of cytopiloyne on insulin transcription, $28 \mu \mathrm{M}$ cytopiloyne increased the intracellular insulin levels 5-fold compared to control treatment in these cells, and this effect on insulin content was dose dependent (Figure 3(c)). The overall data suggest that cytopiloyne stimulates insulin expression in pancreatic $\beta$ cells.

3.4. Cytopiloyne Increases Calcium Influx, DAG Generation, and PKC $\alpha$ Activation. Secondary messengers such as calcium and DAG are involved in a variety of signaling pathways in $\beta$ cells [31-35]. We wanted to understand the mechanism of cytopiloyne in the insulin expression and the release in 
TABLE 2: Blood insulin levels following a single oral dose of cytopiloyne in fed $\mathrm{db} / \mathrm{db}$ mice. Diabetic $\mathrm{db} / \mathrm{db}$ mice aged 6 to 8 weeks received the same treatment as those in Table 1 . Blood samples at the indicated time interval $(0,0.5,1,2$, and $4 \mathrm{~h})$ were collected from the mice and the insulin levels in each blood sample were determined using ELISA kits. The number of mice $(n)$ is indicated in parentheses in the first column.

\begin{tabular}{|c|c|c|c|c|c|}
\hline \multirow{2}{*}{ Treatment } & \multicolumn{5}{|c|}{ Blood insulin level $(\mu \mathrm{g} / \mathrm{L})$} \\
\hline & 0 & 0.5 & 1 & 2 & $4(\mathrm{~h})$ \\
\hline Vehicle $(n=8)$ & $13.8 \pm 1.9$ & $11.5 \pm 1.9$ & $10.3 \pm 2.4$ & $8.3 \pm 0.7$ & $8.6 \pm 1.9$ \\
\hline GLM $2.5 \mathrm{mg} / \mathrm{kg}(n=6)$ & $13.9 \pm 1.2$ & $19.3 \pm 4.2$ & $26.3 \pm 3.3^{*}$ & $15.9 \pm 1.7^{*}$ & $11.8 \pm 2.1^{*}$ \\
\hline $\mathrm{CP} 0.1 \mathrm{mg} / \mathrm{kg}(n=5)$ & $17.2 \pm 4.7$ & $21.0 \pm 1.3^{*}$ & $15.5 \pm 0.6^{*}$ & $14.1 \pm 0.5$ & $9.7 \pm 1.3$ \\
\hline $\mathrm{CP} 0.5 \mathrm{mg} / \mathrm{kg}(n=5)$ & $15.7 \pm 1.9$ & $22.6 \pm 1.9^{*}$ & $16.0 \pm 2.4^{*}$ & $12.8 \pm 0.7^{*}$ & $12.2 \pm 1.9$ \\
\hline $\mathrm{CP} 2.5 \mathrm{mg} / \mathrm{kg}(n=5)$ & $12.5 \pm 1.2$ & $25.5 \pm 1.2^{*}$ & $18.9 \pm 3.3^{*}$ & $17.6 \pm 1.7^{*}$ & $8.9 \pm 2.1$ \\
\hline
\end{tabular}

${ }^{*} P<0.05$ as determined by ANOVA.

$\beta$ cells. Our data showed that RIN-m5F cells responded to glucose and cytopiloyne in a similar way to primary rat islet cells (Figures 3(a) and 3(b)). Therefore, we used RIN-m5F cells to test the effect of cytopiloyne on calcium mobilization. We found that $16.7 \mathrm{mM}$ glucose significantly increased intracellular calcium in $\beta$ cells (Figure 4(a)). Similarly, cytopiloyne increased the level of intracellular calcium in a dose-dependent manner (Figure 4(a)). Next, we determined the effect of cytopiloyne on the production of lipids, DAG, and cholesterol, in RIN-m5F cells. PMA, glimepiride, and $16.7 \mathrm{mM}$ glucose significantly increased the level of DAG in comparison with the vehicle control (Figure 4(b)). Of note, cytopiloyne dose dependently increased the level of DAG but not cholesterol (Figure 4(b)). Because PKC $\alpha$ has been previously implicated in insulin secretion of $\beta$ cells [31,33], we next assessed the effect of cytopiloyne on PKC $\alpha$ activation by examining its translocation and phosphorylation. Like PMA and $16.7 \mathrm{mM}$ glucose, cytopiloyne dose dependently increased the membrane portion of PKC $\alpha$ (Figure 4(c)). Besides, like PMA, cytopiloyne increased the phosphorylation of PKC $\alpha$ (Figure 4(d)). This increase was abolished by nimodipine, a calcium channel blocker, and EGTA, a calcium chelator (Figure 4(d)). The data suggest that cytopiloyne activates PKC $\alpha$ through an increase of its activators, calcium and DAG.

3.5. Cytopiloyne Increases Insulin Secretion and Transcription via $P K C \alpha$. Next, we tested whether PKC $\alpha$ regulated cytopiloyne-mediated insulin secretion in $\beta$ cells. We found that cytopiloyne stimulated insulin secretion in $\beta$ cells, similar to what was observed in positive controls, $16.7 \mathrm{mM}$ glucose and PMA (Figure 5(a)). By contrast, GF109203X, a PKC inhibitor, inhibited cytopiloyne- and PMA-induced insulin secretion (Figure 5(a)). Accordingly, overexpression of a dominant-negative mutant of PKC $\alpha$ decreased cytopiloyneand PMA-mediated insulin secretion (Figure 5(b)). On the contrary, overexpression of this mutant only slightly, if at all, inhibited glucose-mediated insulin secretion (Figure 5(b)). These data showed that cytopiloyne increased insulin secretion in $\beta$ cells in a PKC $\alpha$-dependent manner. We also tested the involvement of $\mathrm{PKC} \alpha$ in insulin transcription in $\beta$ cells. We found that like $16.7 \mathrm{mM}$ glucose and PMA, cytopiloyne stimulated insulin transcription in $\beta$ cells (Figure 5(c)). GF109203X completely abolished cytopiloyne-, glucose-, and PMA-mediated insulin transcription (Figure 5(c)). Similarly, overexpression of a dominant-negative PKC $\alpha$ significantly inhibited insulin transcription (Figure 5(d)). These data revealed that cytopiloyne increased insulin transcription in $\beta$ cells via PKC $\alpha$. Furthermore, we tested whether calcium mobilization affected cytopiloyne-mediated insulin secretion. We found that calcium intervention inhibited the insulin secretion by cytopiloyne in RIN-m5F cells (Figure 5(e)) and rat $\beta$ pancreatic islets (see the species list in the Supplementary Material of Figure 4 available online at http://dx.doi.org/10.1155/2013/685642).

In summary, our mechanistic data suggest that cytopiloyne enhances insulin secretion and expression in $\beta$ cells via the regulation of PKC $\alpha$ by calcium and DAG. The increase of insulin production in $\beta$ cells and islet protection is associated with the therapy of cytopiloyne for T2D (Figure 6).

\section{Discussion and Conclusions}

Plants provide a promising source of anti-diabetic medicines. Cytopiloyne, a plant polyacetylene, represents a new class of anti-diabetic chemotherapeutics. This study not only demonstrates the anti-diabetic efficacy of cytopiloyne, but also reveals the mechanism of the anti-diabetic actions of cytopiloyne in cell and mouse models.

Cytopiloyne has several unique benefits over current secretagogues in the market, including enhancement of insulin expression and maintenance of islet architecture. First, nutrients such as glucose can stimulate insulin biosynthesis at transcriptional and translational levels and the secretion of insulin in $\beta$ cells $[1,36]$. However, current secretagogues for diabetes can stimulate insulin secretion but not insulin biosynthesis. Unexpectedly, cytopiloyne can increase the level of insulin mRNA and protein, and it may be functionally superior to sulfonylureas (Figure 3). Second, cytopiloyne improved islet protection and resulted in a higher survival rate of $\mathrm{db} / \mathrm{db}$ mice than glimepiride or vehicle control (Figure $1(\mathrm{~F})$ and see the species list in the Supplementary Material of Table 1 available online at http://dx.doi.org/10.1155/2013/685642). Similarly, cytopiloyne was reported to maintain pancreatic islet architecture in NOD mice, a type 1 diabetes model [18]. Whether cytopiloyne employs the same mechanism in prevention of $\beta$ cell death in both types of diabetes needs to be further investigated.

Cytopiloyne has other advantages over glimepiride. First, cytopiloyne is a relatively potent anti-diabetic compound 


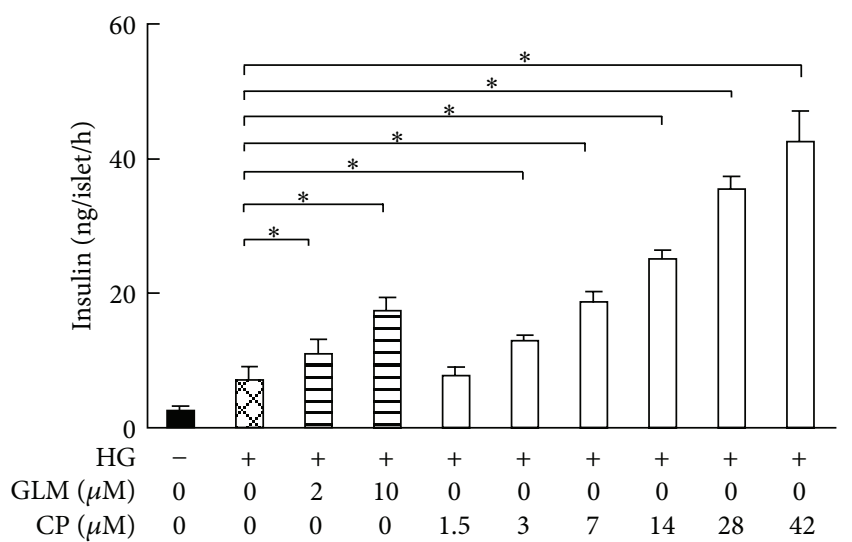

(a)

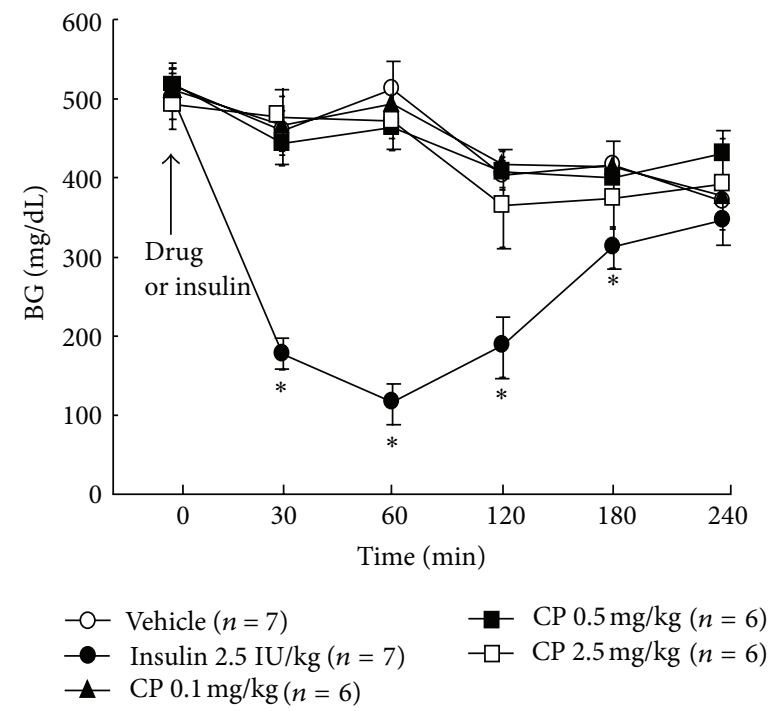

(b)

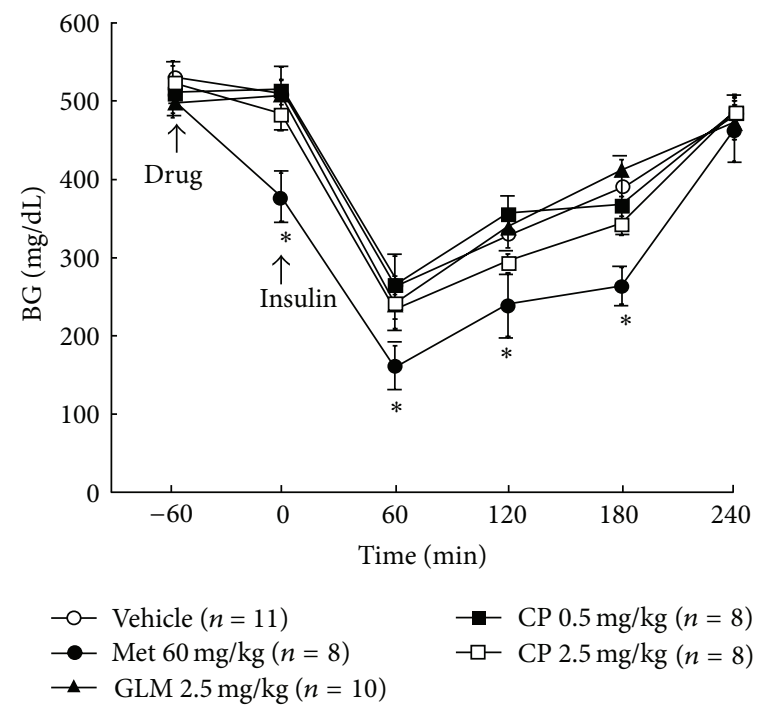

(c)

FIGURE 2: Cytopiloyne-mediated insulin secretion depends on pancreatic $\beta$ cells. (a) Rat pancreatic islets were incubated with KRB buffer containing vehicle, glimepiride (GLM, 0 to $10 \mu \mathrm{M}$ ), or cytopiloyne (CP, 1.5 to $42 \mu \mathrm{M}$ ) in the absence or presence of $16.7 \mathrm{mM}$ glucose (HG). The insulin levels were determined using an insulin ELISA kit. The data are presented as mean \pm SEM of 3 independent experiments. (b) Fed C57BL mice, which had already received an injection of STZ, were administered an oral dose of vehicle, cytopiloyne (CP, $0.1,0.5$, and $2.5 \mathrm{mg} / \mathrm{kg}$ ), and an intraperitoneal injection of insulin (Ins, $2.5 \mathrm{IU} / \mathrm{kg}$ ). Postprandial blood sugar levels in the STZ-treated mice were determined using a glucometer. (c) Fed C57BL mice, which had already received STZ, were orally administered a single dose of vehicle, cytopiloyne (CP, 0.5 and $2.5 \mathrm{mg} / \mathrm{kg}$ ), glimepiride (GLM, $2.5 \mathrm{mg} / \mathrm{kg}$ ), or metformin (Met, $60 \mathrm{mg} / \mathrm{kg}$ ), followed by an intraperitoneal injection with insulin (Ins). Postprandial blood sugar levels in the STZ-treated mice were determined using a glucometer. Results are expressed as mean \pm SEM from 3 independent experiments, and $P<0.05$ was considered to be statistically significant $\left(^{*}\right)$. The number of mice $(n)$ is indicated in parentheses.

as compared to glimepiride. Cytopiloyne induced similar anti-diabetic effects as glimepiride at one-fifth of the dose and modestly better anti-diabetic effects at the same dose (Figure 1 and Tables 1 and 2). In comparison with lowpotency insulin secretagogues, cytopiloyne may have other benefits such as increased efficacy or decreased toxicity. Second, cytopiloyne may have a different mechanism of action as that of glimepiride, based on the large differences in their chemical structures. In fact, cytopiloyne, but not glimepiride, is able to promote insulin transcription (Figure 3 ) and confer islet protection (Figure $1(\mathrm{~F})$ ). Cytopiloyne is structurally different from currently known secretagogues and thus may represent a new class of anti-diabetic agents. Thus, studying the anti-diabetic mechanism of cytopiloyne may elucidate 


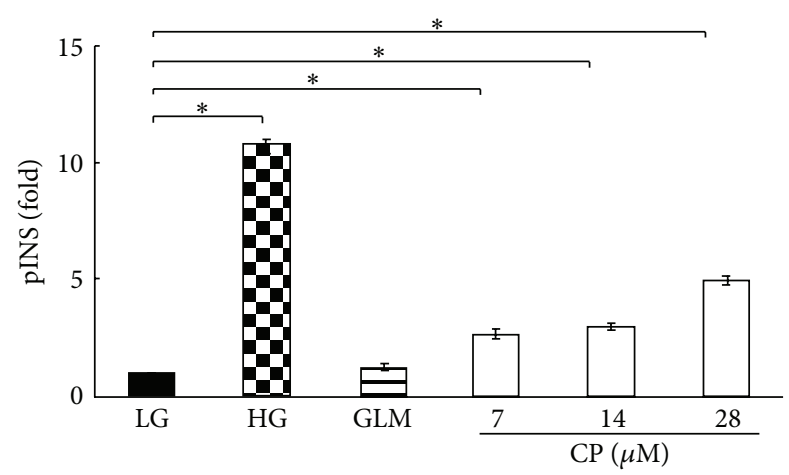

(a)
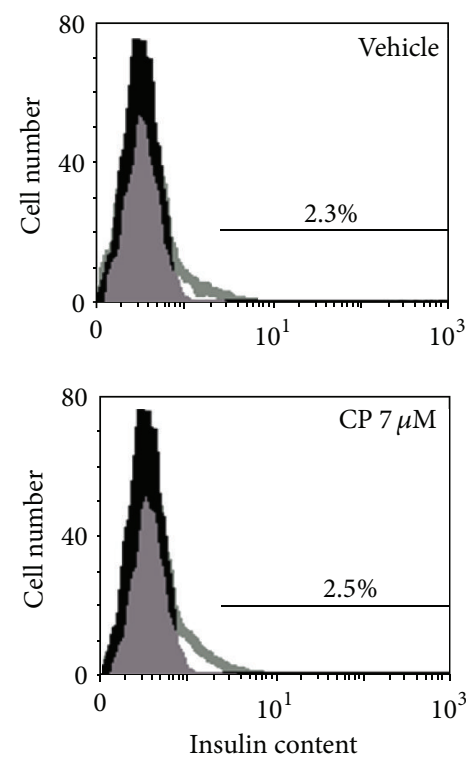

Insulin content
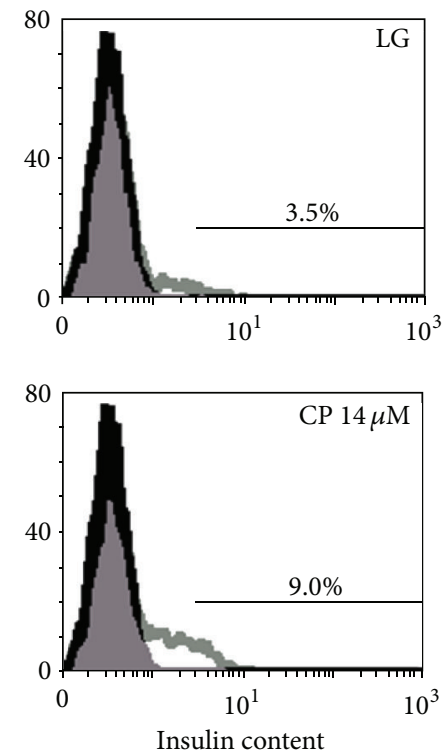

(c)

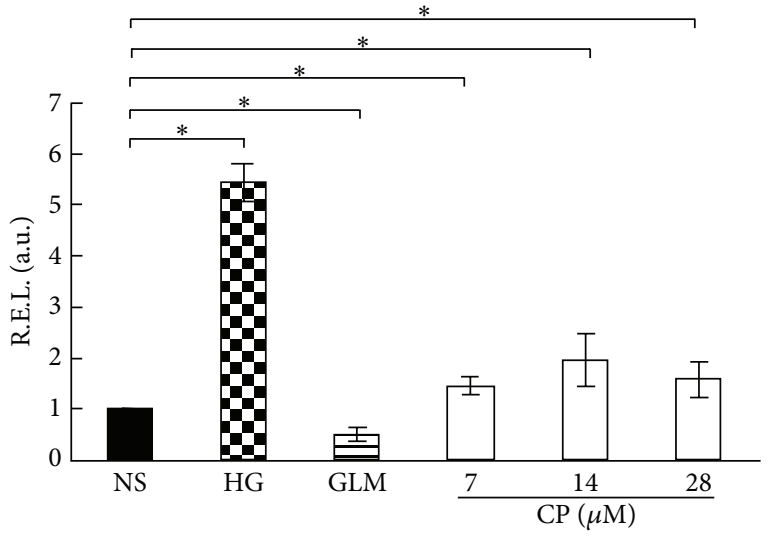

(b)
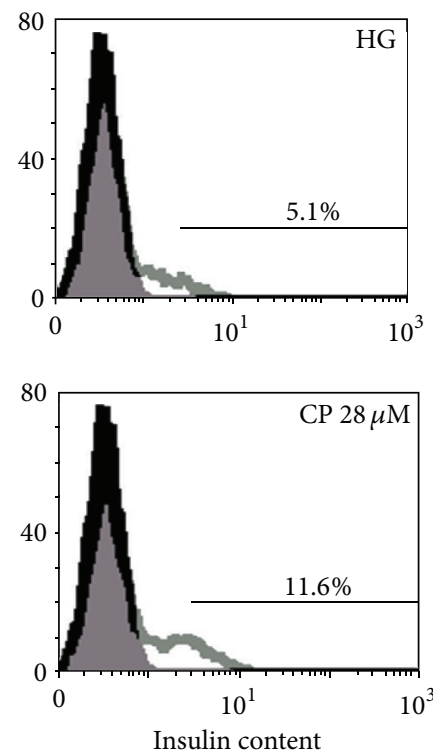

FIGURE 3: Increase in insulin mRNA and protein content by cytopiloyne in pancreatic islets. (a) RIN-m5F $\beta$ cells transfected with phINS-Luc and pRL-TK plasmids were incubated with medium containing $3.3 \mathrm{mM}$ glucose in the presence of vehicle (LG), glimepiride (GLM, $10 \mu \mathrm{M}$ ), and cytopiloyne $(7,14$, or $28 \mu \mathrm{M})$ or $16.7 \mathrm{mM}$ glucose (HG). Insulin promoter activity expressed as fold change relative to vehicle-treated control was measured using dual luciferase assays. (b) The relative expression level (R.E.L.) of insulin relative to L13 in rat primary pancreatic islets, which were already treated with $3.3 \mathrm{mM}$ glucose in the presence of vehicle (LG), glimepiride (GLM, $10 \mu \mathrm{M})$, or cytopiloyne (7, 14, or $28 \mu \mathrm{M}$ ) or $16.7 \mathrm{mM}$ glucose (HG) for $24 \mathrm{~h}$, was determined by real-time RT-PCR. (c) Rat pancreatic islets received the same treatments as the islets in (b) in the presence of brefeldin A for $24 \mathrm{~h}$. After anti-insulin antibody staining, these cells underwent FACS analysis. The percentage of insulin-positive $\beta$ cells is shown. Results are expressed as mean \pm SEM from 3 independent experiments, and $P<0.05$ was considered to be statistically significant $\left({ }^{*}\right)$.

novel pathways that participate in insulin synthesis/secretion and islet preservation and the development of anti-diabetic agents.

No drug is perfect, and cytopiloyne presents challenges like other therapies. Current secretagogues occasionally reduce blood sugar to a detrimental degree, a condition known as hypoglycemia. The development of blood glucose-dependent secretagogues would prevent this dangerous side effect. At a low dose (e.g., $3 \mu \mathrm{M})$, cytopiloyne stimulates insulin secretion in pancreatic islets in a glucose-dependent manner (see the species list in the
Supplementary Material of Figure 3 available online at http://dx.doi.org/10.1155/2013/685642). However, a high dose of cytopiloyne can still stimulate insulin secretion to some extent even in the absence of glucose (Figure 2(a)). The data show that cytopiloyne-mediated insulin secretion is partially glucose dependent. Thus, at a high dose, cytopiloyne may pose a similar potential risk for hypoglycemia as sulfonylureas, particularly in patients with low blood glucose levels. However, this problem may be alleviated by decreased dosage or use in combination with a sensitizer such as metformin, which has no hypoglycemic effect. Additionally, it should be 


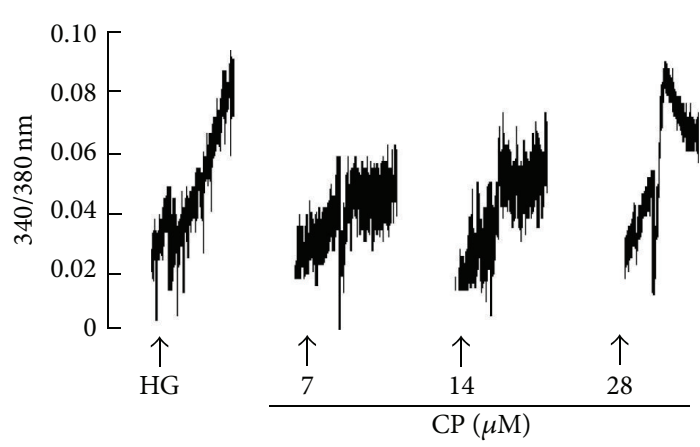

(a)

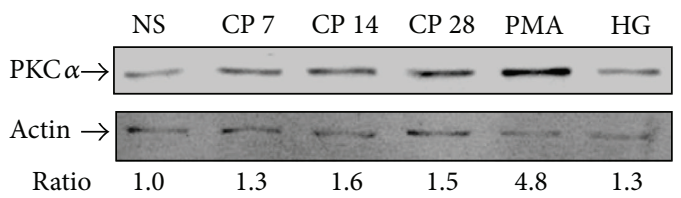

(c)

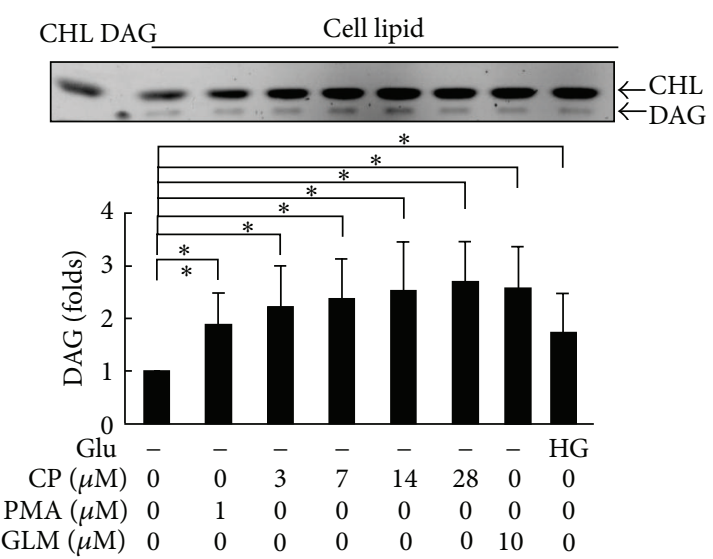

(b)

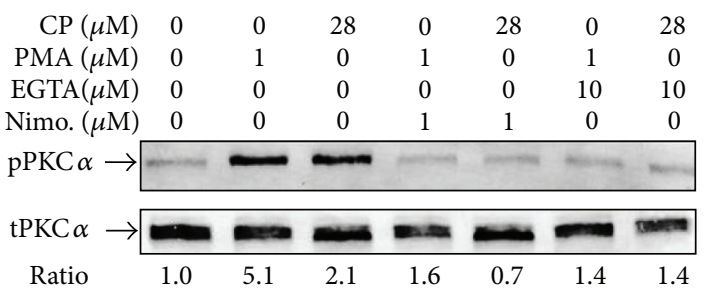

(d)

FIGURE 4: Effects of cytopiloyne on calcium mobilization, DAG generation, and PKC $\alpha$ activation. (a) After Fura 2-AM loading, RIN-m5F cells were stimulated with $16.7 \mathrm{mM}$ glucose (HG) and cytopiloyne (CP) at 7, 14, and $28 \mu \mathrm{M}$. The level of intracellular calcium, as shown by the 340/380 nm ratio, was detected using a fluorescence spectrophotometer. (b) RIN-m5F cells were stimulated with glucose, cytopiloyne (CP), PMA, and glimepiride (GLM). Total cell lipids and their commercial standards, DAG and cholesterol (CHL), were resolved on a silica thin layer plate. The quantity of DAG and cholesterol in each sample is replotted into histograms. (c) RIN-m5F cells were incubated with vehicle (NS), cytopiloyne (CP, 7, 14, and $28 \mu \mathrm{M})$, PMA $(1 \mu \mathrm{M})$, and $16.7 \mathrm{mM}$ glucose (HG). Membrane proteins of each sample were subjected to Western blot with anti-PKC $\alpha$ and anti-actin antibodies. (d) RIN-m5F cells were incubated with vehicle, cytopiloyne (28 $\mu \mathrm{M})$, and PMA $(1 \mu \mathrm{M})$ in the absence or presence of EGTA $(10 \mu \mathrm{M})$ and nimodipine (Nimo, $1 \mu \mathrm{M})$. Total proteins were subjected to Western blot with anti$\mathrm{PKC} \alpha(\mathrm{t}-\mathrm{PKC} \alpha)$ and anti-phospho-PKC $\alpha(\mathrm{p}-\mathrm{PKC} \alpha)$ antibodies.

noted that insulin secretagogues have a low clinical incidence of hypoglycemia, because patients with T2D usually have higher insulin resistance than healthy subjects.

Cytopiloyne contains a glucose moiety and therefore it is conceivable that it acts at glucose receptors to mediate insulin expression and secretion. However, our data argue against this possibility. At $28 \mu \mathrm{M}$, the concentration of glucose in cytopiloyne is about 600 times lower than the glucose in our experiments $(16.7 \mathrm{mM})$. However, upregulation of insulin transcription by cytopiloyne at the same concentration is $40 \%$ (not $0.17 \%$ ) of the up-regulation by $16.7 \mathrm{mM}$ glucose (Figures 3(a) and 3(b)). Notably, $28 \mu \mathrm{M}$ cytopiloyne was less effective in inducing insulin mRNA production but more effective in increasing insulin protein levels than $16.7 \mathrm{mM}$ glucose in islets (Figure 3). This discrepancy may be due to differences in the regulation of insulin at the mRNA and protein levels by cytopiloyne. Indeed, glucose and GLP1 strongly stimulate insulin translation but only modestly stimulate insulin transcription in $\beta$ cells $[1,37]$.

DAG and calcium are common secondary messengers in $\beta$ cells [31-35]. Both messengers activate PKC $\alpha$. PKC $\alpha$ has been found to be involved in insulin secretion mediated by PMA and glucose [31-35] although the authors of one study excluded the participation of PKC $\alpha$ in glucose-mediated insulin secretion [31-35]. Consistent with the literature, our study shows that PMA activates PKC $\alpha$ in $\beta$ cells to a greater extent than glucose (Figure 4(c)). In this study, cytopiloyne dose dependently activated PKC $\alpha$ (Figures 4(c) and 4(d)). PKC $\alpha$ activation of cytopiloyne was dependent on calcium (Figure 4(d)) and probably also DAG. Furthermore, interference with the PKC inhibitor, GF109203X, and the dominantnegative mutant of PKC $\alpha$ inhibited cytopiloyne-mediated insulin secretion/expression in $\beta$ cells (Figures 5(a)-5(d)). The insulin secretion/expression of cytopiloyne is calcium dependent (Figure 5(e)). Therefore, our data suggest that cytopiloyne increases insulin production via $\mathrm{PKC} \alpha$ activation that involves secondary messengers (Figure 6).

In conclusion, we showed that cytopiloyne suppressed the progression of $\mathrm{T} 2 \mathrm{D}$ in $\mathrm{db} / \mathrm{db}$ mice as evidenced by the decrease in the levels of blood glucose and $\mathrm{HbA}_{1 \mathrm{c}}$, glucose tolerance, and islet atrophy in $\mathrm{db} / \mathrm{db}$ mice. Insulin release/expression and protection of $\beta$ cells contributed 


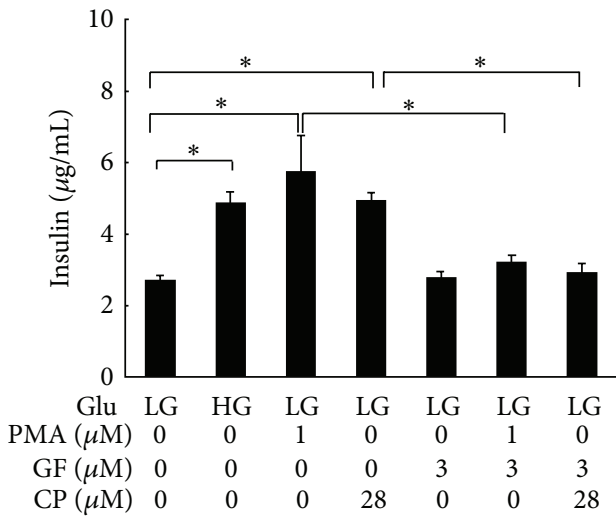

(a)

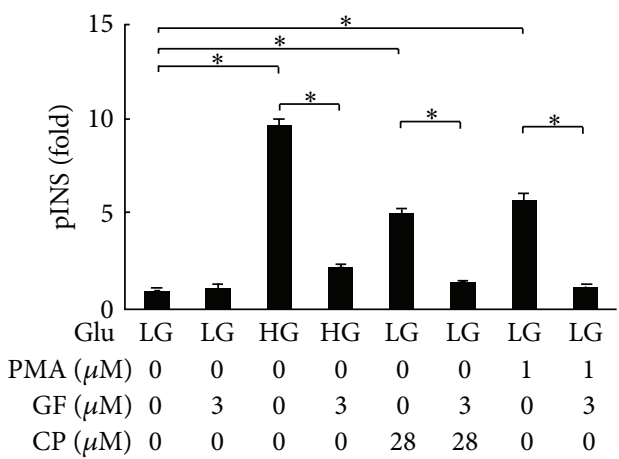

(c)

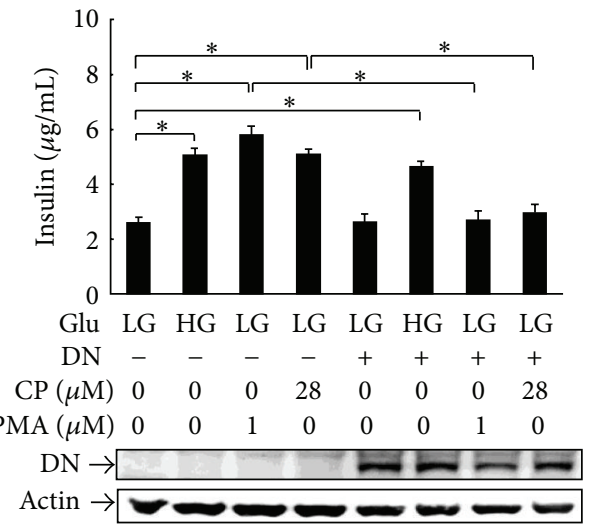

(b)

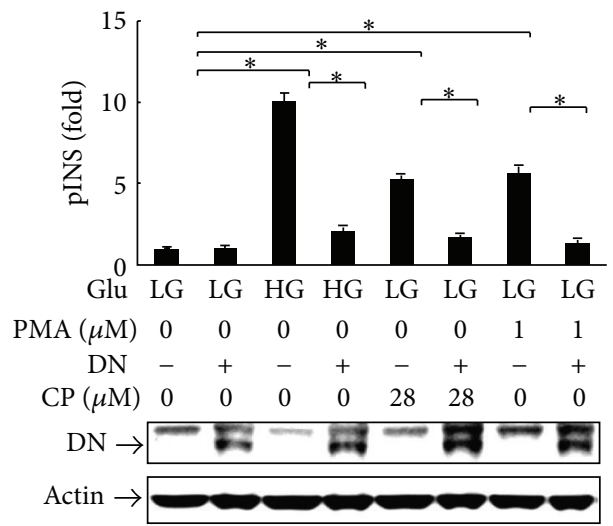

(d)

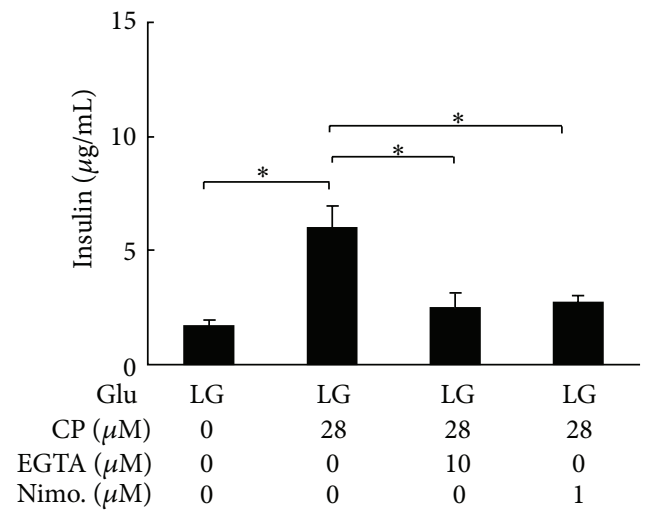

(e)

FIGURE 5: Cytopiloyne-mediated insulin secretion and expression are abolished by a dominant-negative mutant and a PKC $\alpha$ inhibitor. (a) RIN-m5F cells were grown in medium with $16.7 \mathrm{mM}$ glucose (HG) or $3.3 \mathrm{mM}$ glucose (LG) in the presence of PMA ( $1 \mu \mathrm{M})$, GF109203X $(\mathrm{GF}, 3 \mu \mathrm{M})$, and cytopiloyne $(\mathrm{CP}, 28 \mu \mathrm{M})$. The insulin level in the supernatants was determined using an ELISA kit. (b) RIN-m5F cells were transfected with $5 \mu \mathrm{g}$ of pHACE-PKC $\alpha$ DN (+) or pcDNA3 (-) plasmid and grown in medium supplemented with $16.7 \mathrm{mM}(\mathrm{HG})$ or $3.3 \mathrm{mM}$ glucose (LG) in the presence of PMA and cytopiloyne. The insulin level was determined as described in (a). The expression level of dominantnegative HA-tagged $\mathrm{PKC} \alpha(\mathrm{DN})$ and an internal control, actin, in the transfected cells was determined by Western blot using anti-HA and antiactin antibodies. (c) RIN-m5F cells were transfected with phINS-Luc and pRL-TK plasmids. The cells were grown in medium with $16.7 \mathrm{mM}$ (HG) or $3.3 \mathrm{mM}$ glucose (LG) in the absence and presence of PMA, GF109203X, and cytopiloyne. The activity of the insulin promoter (pINS) in fold was measured using dual luciferase assays. (d) RIN-m5F cells were transfected with phINS-Luc and pRL-TK plus $5 \mu \mathrm{g}$ of pHACE-PKC $\alpha$ $\mathrm{DN}(+)$ or pcDNA3 (-) plasmids. The cells were grown in medium with $16.7 \mathrm{mM}$ (HG) or $3.3 \mathrm{mM}$ glucose (LG) in the absence or presence of PMA and cytopiloyne. Insulin promoter activity expressed as fold change relative to vehicle-treated control was measured using dual luciferase assays. The expression level of dominant-negative HA-tagged PKC $\alpha(\mathrm{DN})$ and actin in the transfected cells was determined using Western blot and anti-HA and anti-actin antibodies. (e) RIN-m5F cells were grown in medium with $3.3 \mathrm{mM}$ glucose (LG) and/or cytopiloyne (CP, $28 \mu \mathrm{M})$ in the presence of EGTA $(10 \mu \mathrm{M})$ or nimodipine (Nimo, $1 \mu \mathrm{M})$. The insulin level in the supernatants was determined. 


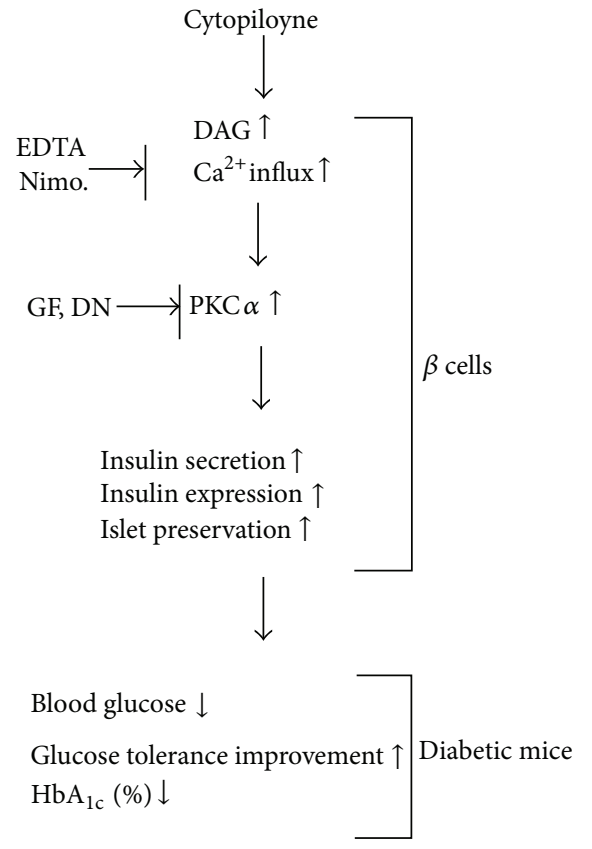

FIGURE 6: Schematic diagram of the likely mechanism by which cytopiloyne treats T2D in diabetic mouse models. Cytopiloyne shows anti-diabetic effects in diabetic mice, as evidenced by a reduction in the levels of blood sugar and glycosylated $\mathrm{HbA}_{1 \mathrm{c}}$, improvement of glucose tolerance, and its regulation of $\beta$-cell functions (e.g., insulin secretion, insulin expression, and pancreatic islet protection). The regulation of insulin secretion/expression in $\beta$ cells by cytopiloyne involves PKC $\alpha$ and its activators, calcium, and DAG.

to this suppression. We also showed that cytopiloyne upregulated insulin release/expression that involved PKC $\alpha$ activation and its activators, calcium and likely DAG. This study reveals the anti-diabetic mode of action of cytopiloyne and suggests its use as a new anti-diabetic agent.

\begin{tabular}{|c|c|}
\hline \multicolumn{2}{|c|}{ Abbreviations } \\
\hline BW: & Body weight \\
\hline DAG: & Diacylglycerol \\
\hline DMSO: & Dimethyl sulfoxide \\
\hline FACS: & Fluorescence-activated cell sorting \\
\hline GLP-1: & Glucagon-like peptide-1 \\
\hline $\mathrm{HbA}_{1 \mathrm{c}}$ : & Hemoglobin $A_{1 c}$ \\
\hline IPGTT: & Intraperitoneal glucose tolerance test \\
\hline IP3: & Phosphatidylinositol triphosphate \\
\hline KRB: & Krebs-Ringer bicarbonate \\
\hline PBS: & Phosphate-buffered saline \\
\hline PKA: & Protein kinase A \\
\hline PKC: & Protein kinase $\mathrm{C}$ \\
\hline PMA: & Phorbol 12-myristate 13-acetate \\
\hline STZ: & Streptozocin \\
\hline T2D: & Type 2 diabetes. \\
\hline
\end{tabular}

\section{Conflict of Interests}

The authors declare that they have no conflict of interests.

\section{Acknowledgments}

The authors thank Drs. H. Kuhn and A. Peña for paper editing and Dr. J. T. Cheng, Dr. J. R. Sheu, and the Yang lab members for constructive discussion and technical assistance.The authors also thank Dr. J.-W. Soh (Inha University, Korea) for his generous gift of plasmid pHACE-PKC $\alpha$-DN. This work was supported by the National Science Council (NSC942320-B-001-028, NSC95-2320-B-001-012, and NSC97-2320B-005-001-MY3) and Academia Sinica (99-CDA-L11).

\section{References}

[1] B. Wicksteed, C. Alarcon, I. Briaud, M. K. Lingohr, and C. J. Rhodes, "Glucose-induced translational control of proinsulin biosynthesis is proportional to preproinsulin mRNA levels in islet $\beta$-cells but not regulated via a positive feedback of secreted insulin," Journal of Biological Chemistry, vol. 278, no. 43, pp. 42080-42090, 2003.

[2] P. Newsholme, C. Gaudel, and N. H. McClenaghan, "Nutrient regulation of insulin secretion and $\beta$-cell functional integrity," Advances in Experimental Medicine and Biology, vol. 654, pp. 91-114, 2010.

[3] M. Laakso, "Insulin resistance and its impact on the approach to therapy of type 2 diabetes," International Journal of Clinical Practice, Supplement, no. 121, pp. 8-12, 2001.

[4] R. S. Clements and D. S. H. Bell, "Complications of diabetes: prevalence, detection, current treatment, and prognosis," American Journal of Medicine, vol. 79, no. 5, pp. 2-7, 1985.

[5] J. P. Boyle, M. M. Engelgau, T. J. Thompson et al., "Estimating prevalence of type 1 and type 2 diabetes in a population of African Americans with diabetes mellitus," American Journal of Epidemiology, vol. 149, no. 1, pp. 55-63, 1999.

[6] A. S. Attele, Y. P. Zhou, J. T. Xie et al., "Antidiabetic effects of Panax ginseng berry extract and the identification of an effective component," Diabetes, vol. 51, no. 6, pp. 1851-1858, 2002.

[7] A. J. Krentz and C. J. Bailey, "Oral antidiabetic agents: current role in type 2 diabetes mellitus," Drugs, vol. 65, no. 3, pp. 385411, 2005.

[8] H. C. S. Howlett and C. J. Bailey, "A risk-benefit assessment of metformin in type 2 diabetes mellitus," Drug Safety, vol. 20, no. 6, pp. 489-503, 1999.

[9] J. Q. Purnell and C. Weyer, "Weight effect of current and experimental drugs for diabetes mellitus: from promotion to alleviation of obesity," Treatments in Endocrinology, vol. 2, no. 1, pp. 33-47, 2003.

[10] J. M. Egan, A. Bulotta, H. Hui, and R. Perfetti, "GLP-1 receptor agonists are growth and differentiation factors for pancreatic islet beta cells," Diabetes/Metabolism Research and Reviews, vol. 19, no. 2, pp. 115-123, 2003.

[11] R. J. Marles and N. R. Farnsworth, "Antidiabetic plants and their active constituents," Phytomedicine, vol. 2, no. 2, pp. 137-189, 1995.

[12] M. Habeck, "Diabetes treatments get sweet help from nature," Nature Medicine, vol. 9, no. 10, p. 1228, 2003.

[13] A. Y. Oubré, T. J. Carlson, S. R. King, and G. M. Reaven, "From plant to patient: an ethnomedical approach to the identification 
of new drugs for the treatment of NIDDM," Diabetologia, vol. 40, no. 5, pp. 614-617, 1997.

[14] F. J. Alarcon-Aguilar, R. Roman-Ramos, J. L. Flores-Saenz, and F. Aguirre-Garcia, "Investigation on the hypoglycaemic effects of extracts of four Mexican medicinal plants in normal and alloxan-diabetic mice," Phytotherapy Research, vol. 16, no. 4, pp. 383-386, 2002.

[15] C. C. Lin, "Crude drugs used for the treatment of diabetes mellitus in Taiwan," American Journal of Chinese Medicine, vol. 20, no. 3-4, pp. 269-279, 1992.

[16] R. P. Ubillas, C. D. Mendez, S. D. Jolad et al., "Antihyperglycemic acetylenic glucosides from Bidens pilosa," Planta Medica, vol. 66, no. 1, pp. 82-83, 2000.

[17] S. L. Chang, C. L. T. Chang, Y. M. Chiang et al., "Polyacetylenic compounds and butanol fraction from Bidens pilosa can modulate the differentiation of helper T cells and prevent autoimmune diabetes in non-obese diabetic mice," Planta Medica, vol. 70, no. 11, pp. 1045-1051, 2004.

[18] C. L. T. Chang, S. L. Chang, Y. M. Lee et al., "Cytopiloyne, a polyacetylenic glucoside, prevents type 1 diabetes in nonobese diabetic mice," Journal of Immunology, vol. 178, no. 11, pp. 69846993, 2007.

[19] S. C. Chien, P. H. Young, Y. J. Hsu et al., "Anti-diabetic properties of three common Bidens pilosa variants in Taiwan," Phytochemistry, vol. 70, no. 10, pp. 1246-1254, 2009.

[20] Y. J. Hsu, T. H. Lee, C. L. T. Chang, Y. T. Huang, and W. C. Yang, "Anti-hyperglycemic effects and mechanism of Bidens pilosa water extract," Journal of Ethnopharmacology, vol. 122, no. 2, pp. 379-383, 2009.

[21] T. Harrity, D. Farrelly, A. Tieman et al., "Muraglitazar, a novel dual $(\alpha / \gamma)$ peroxisome proliferator-activated receptor activator, improves diabetes and other metabolic abnormalities and preserves $\beta$-cell function in $\mathrm{db} / \mathrm{db}$ mice," Diabetes, vol. 55 , no. 1, pp. 240-248, 2006.

[22] J. W. Cardinal, D. J. Allan, and D. P. Cameron, "Differential metabolite accumulation may be the cause of strain differences in sensitivity to streptozotocin-induced $\beta$ cell death in inbred mice," Endocrinology, vol. 139, no. 6, pp. 2885-2891, 1998.

[23] R. S. Surwit, M. F. Seldin, C. M. Kuhn, C. Cochrane, and M. N. Feinglos, "Control of expression of insulin resistance and hyperglycemia by different genetic factors in diabetic C57BL/6J mice," Diabetes, vol. 40, no. 1, pp. 82-87, 1991.

[24] W. T. Cefalu, "Animal models of type 2 diabetes: clinical presentation and pathophysiological relevance to the human condition," ILAR Journal, vol. 47, no. 3, pp. 186-198, 2006.

[25] I. Miwa, N. Ichimura, M. Sugiura, Y. Hamada, and S. Taniguchi, "Inhibition of glucose-induced insulin secretion by 4-hydroxy2-nonenal and other lipid peroxidation products," Endocrinology, vol. 141, no. 8, pp. 2767-2772, 2000.

[26] H. H. Sung, J. H. Juang, Y. C. Lin et al., "Transgenic expression of decoy receptor 3 protects islets from spontaneous and chemicalinduced autoimmune destruction in nonobese diabetic mice," Journal of Experimental Medicine, vol. 199, no. 8, pp. 1143-1151, 2004.

[27] E. G. Bligh and W. J. Dyer, "A rapid method of total lipid extraction and purification," Canadian Journal of Biochemistry and Physiology, vol. 37, no. 8, pp. 911-917, 1959.

[28] D. R. Garris and B. L. Garris, "Estrogenic restoration of functional pancreatic islet cytoarchitecture in diabetes $(\mathrm{db} / \mathrm{db})$ mutant C57BL/KsJ mice: relationship to estradiol localization, systemic glycemia, and persistent hyperinsulinemia," Cell and Tissue Research, vol. 319, no. 2, pp. 231-242, 2005.
[29] E. H. Leiter and C. H. Lee, "Mouse models and the genetics of diabetes: is there evidence for genetic overlap between type 1 and type 2 diabetes?” Diabetes, vol. 54, no. 2, pp. S151-S158, 2005.

[30] M. Yamanaka, Y. Itakura, A. Tsuchida, T. Nakagawa, and M. Taiji, "Brain-derived neurotrophic factor (BDNF) prevents the development of diabetes in prediabetic mice," Biomedical Research, vol. 29, no. 3, pp. 147-153, 2008.

[31] S. L. Howell, P. M. Jones, and S. J. Persaud, "Protein kinase $\mathrm{C}$ and the regulation of insulin secretion," Biochemical Society Transactions, vol. 18, no. 1, pp. 114-116, 1990.

[32] S. L. Howell, P. M. Jones, and S. J. Persand, "Regulation of insulin secretion: the role of second messengers," Diabetologia, vol. 37, no. 2, pp. S30-S35, 1994.

[33] P. M. Jones, S. J. Persaud, and S. L. Howell, "Protein kinase C and the regulation of insulin secretion from pancreatic B cells," Journal of Molecular Endocrinology, vol. 6, no. 2, pp. 121-127, 1991.

[34] S. J. Persaud, P. M. Jones, D. Sugden, and S. L. Howell, "Translocation of protein kinase $\mathrm{C}$ in rat islets of Langerhans. Effects of a phorbol ester, carbachol and glucose," FEBS Letters, vol. 245, no. 1-2, pp. 80-84, 1989.

[35] S. G. Straub and G. W. G. Sharp, "Glucose-stimulated signaling pathways in biphasic insulin secretion," Diabetes/Metabolism Research and Reviews, vol. 18, no. 6, pp. 451-463, 2002.

[36] K. Ohneda, H. Ee, and M. German, "Regulation of insulin gene transcription," Seminars in Cell and Developmental Biology, vol. 11, no. 4, pp. 227-233, 2000.

[37] C. Alarcon, B. Wicksteed, and C. J. Rhodes, "Exendin 4 controls insulin production in rat islet beta cells predominantly by potentiation of glucose-stimulated proinsulin biosynthesis at the translational level," Diabetologia, vol. 49, no. 12, pp. 2920 2929, 2006. 


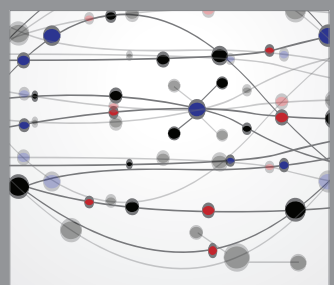

The Scientific World Journal
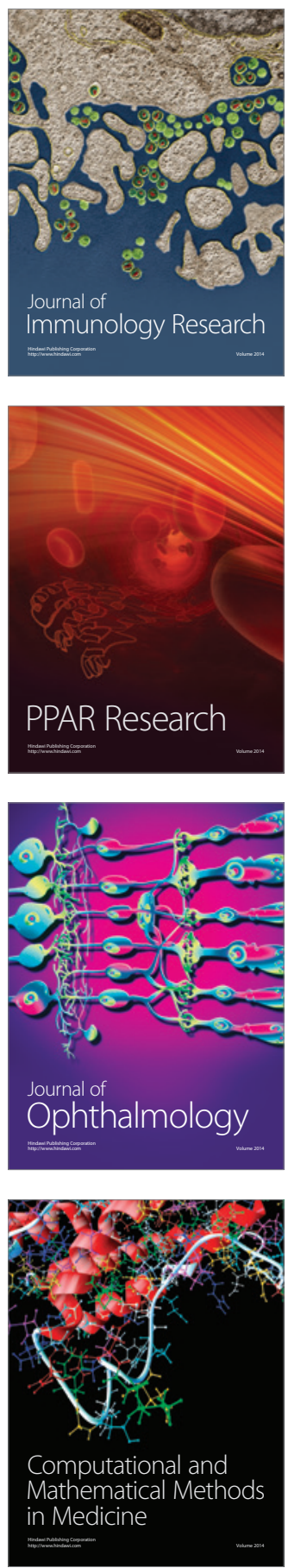

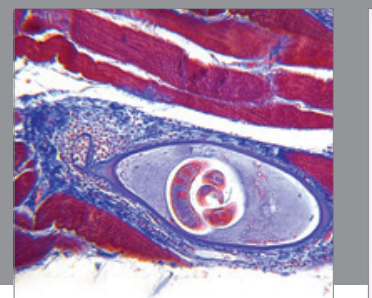

Gastroenterology

Research and Practice
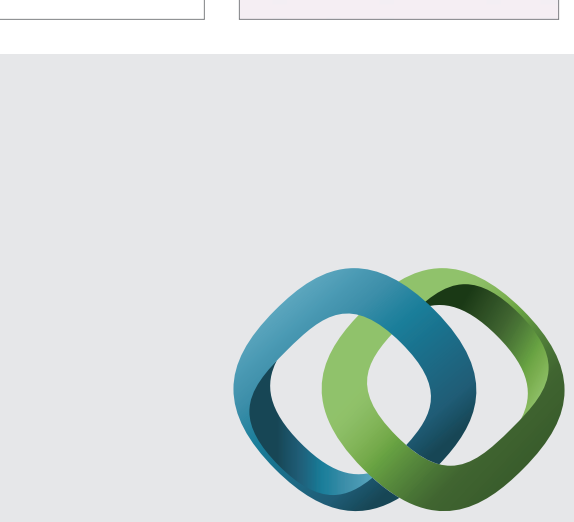

\section{Hindawi}

Submit your manuscripts at

http://www.hindawi.com
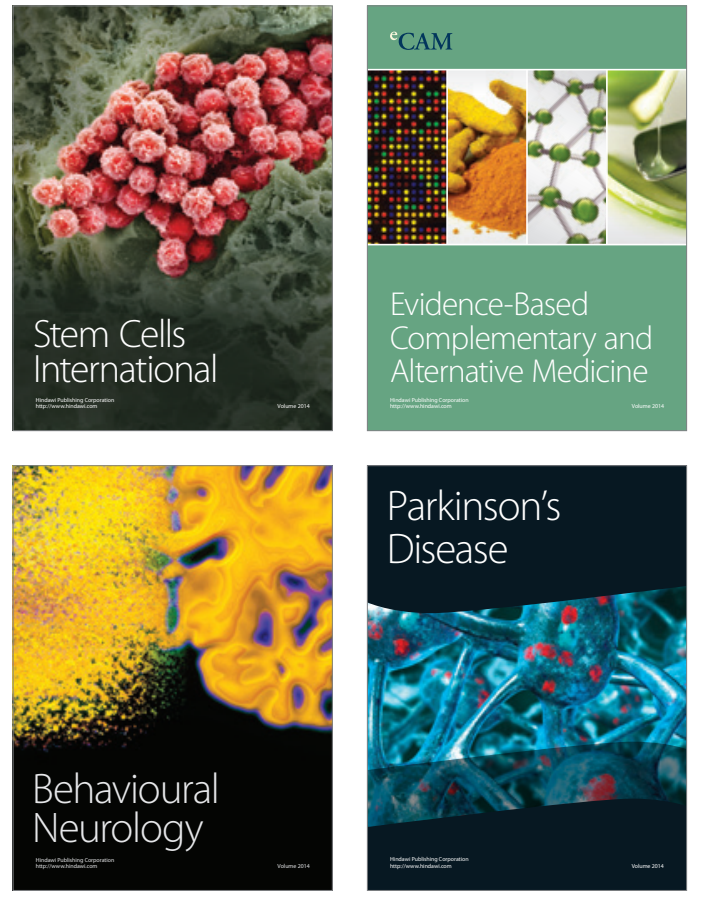
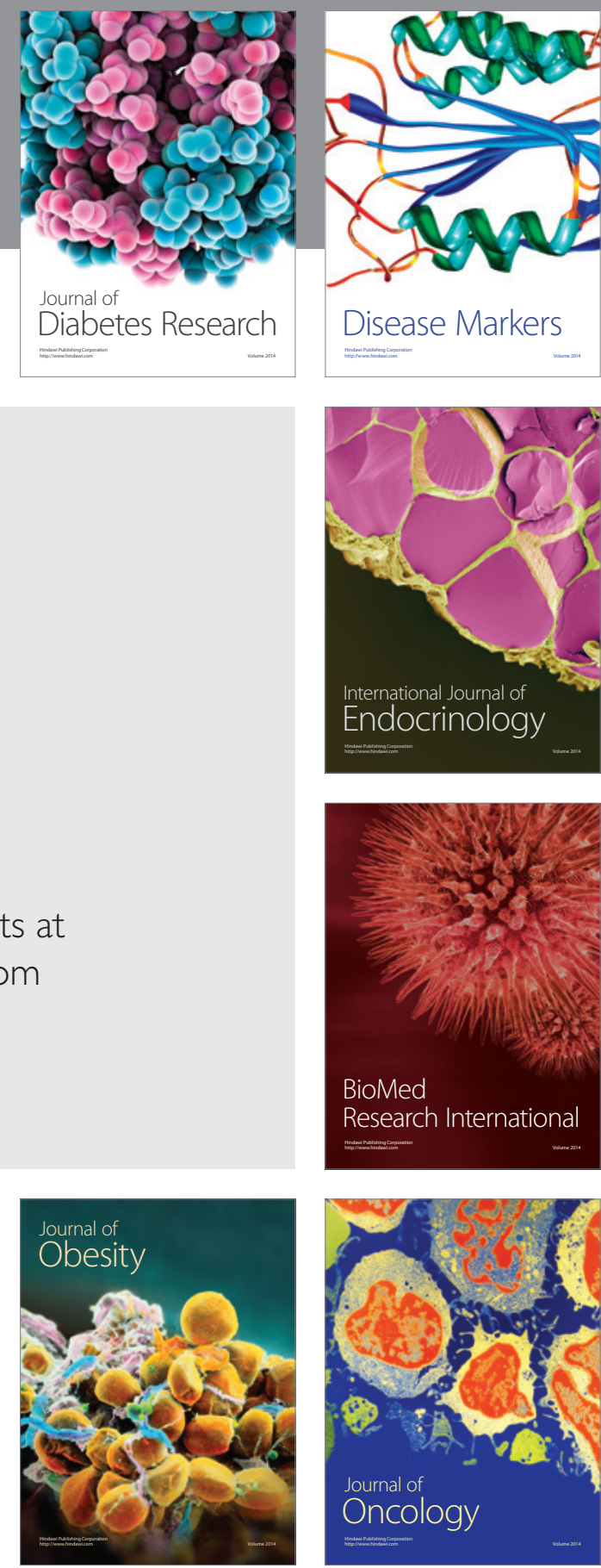

Disease Markers
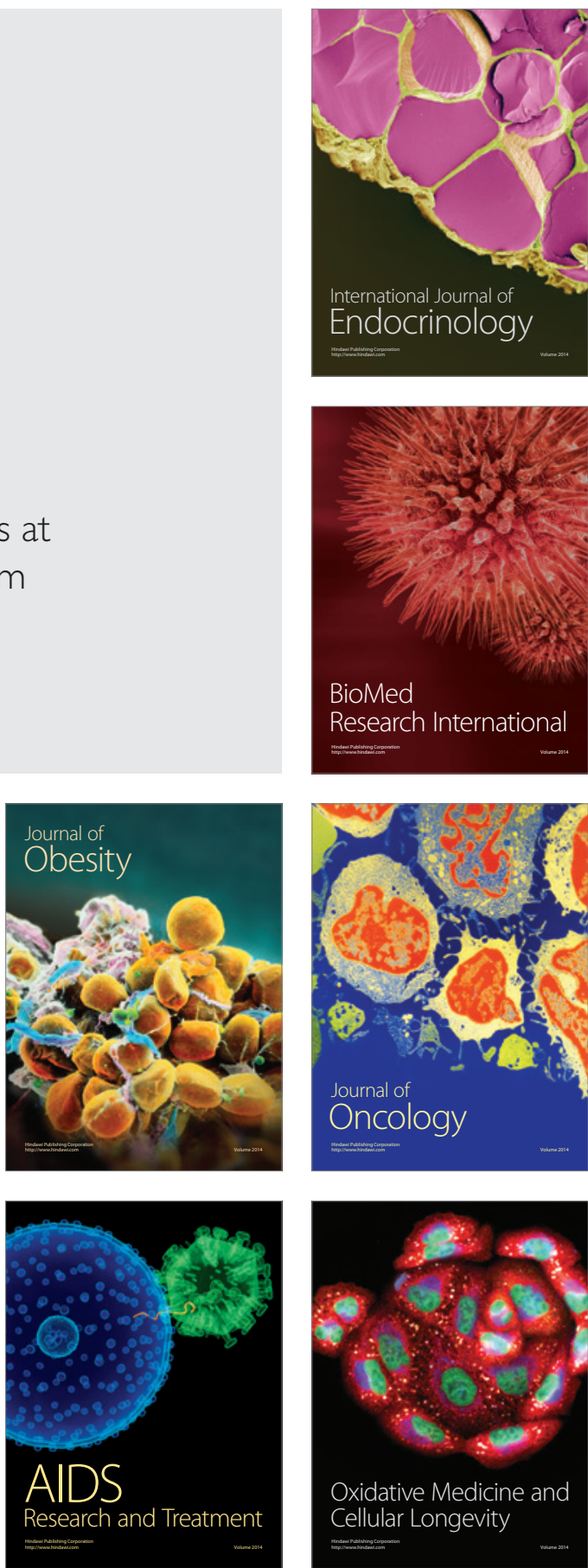